\title{
Autophagy inhibition enables Nrf2 to exaggerate the progression of diabetic cardiomyopathy in mice
}

Huimei Zang ${ }^{1}$, Weiwei Wu ${ }^{1}$, Lei Qi ${ }^{1}$, Wenbin Tan ${ }^{1}$, Prakash Nagarkatti ${ }^{2}$, Mitzi Nagarkatti ${ }^{2}$, Xuejun Wang ${ }^{3}$, Taixing Cui ${ }^{1}$.

${ }^{1}$ Department of Cell Biology and Anatomy, ${ }^{2}$ Department of Pathology, Microbiology and Immunology, School of Medicine, University of South Carolina, Columbia, SC 29208, USA.

${ }^{3}$ Division of Basic Biomedical sciences, University of South Dakota Sanford School of Medicine, Vermillion, SD 57069, USA

A short running title: Nrf2-mediated progression of diabetic cardiomyopathy

Address correspondence: Dr. Taixing Cui, University of South Carolina School of Medicine, Tel: 803-216-3804; Email: taixing.cui@uscmed.sc.edu

\section{ONLINE MATERIALS}

\section{Online Tables}

\section{Supplementary Figures and Figure Legends}




\section{Online Tables}

Online Table 1. Antibody Information

\begin{tabular}{|c|c|c|c|}
\hline Name & MW (kDa) & Characteristics & Sources \\
\hline Anti-Nrf2 & 100 & $\begin{array}{l}\text { Rabbit polyclonal anti-Nrf2 } \\
\text { (WB) }\end{array}$ & $\begin{array}{c}\text { Proteintech } \\
\text { Cat\#: 16396-1-AP }\end{array}$ \\
\hline Anti-LC3 & 14,16 & $\begin{array}{l}\text { Rabbit polyclonal anti-LC3 } \\
\text { (WB) }\end{array}$ & $\begin{array}{l}\text { Sigma-Aldrich } \\
\text { Cat\#: L8918 }\end{array}$ \\
\hline Anti-Atg5 & 56 & $\begin{array}{c}\text { Rabbit polyclonal anti-Atg5(C- } \\
\text { terminal) (WB) }\end{array}$ & $\begin{array}{l}\text { Sigma-Aldrich } \\
\text { Cat\#: A0731 }\end{array}$ \\
\hline Anti-Atg7 & 75 & $\begin{array}{c}\text { Rabbit polyclonal anti-Atg7 } \\
\text { (WB) }\end{array}$ & $\begin{array}{l}\text { Sigma-Aldrich } \\
\text { Cat\#: A2856 }\end{array}$ \\
\hline Anti-Atg16L1 & 66 & $\begin{array}{l}\text { Rabbit polyclonal anti-Atg16L1 } \\
\text { (WB) }\end{array}$ & $\begin{array}{c}\text { Sigma-Aldrich } \\
\text { Cat\#: SAB2103567 }\end{array}$ \\
\hline Anti-Beclin-1 & 60 & $\begin{array}{c}\text { Rabbit polyclonal anti-Beclin-1 } \\
\text { (WB) }\end{array}$ & $\begin{array}{l}\text { Sigma Aldrich } \\
\text { Cat\#: PRS3613 }\end{array}$ \\
\hline Anti-8OHdG & $\mathrm{N} / \mathrm{A}$ & $\begin{array}{c}\text { Mouse monoclonal anti- } \\
\text { 8OHdG(15A3) (IHC) }\end{array}$ & $\begin{array}{c}\text { Santa Cruz } \\
\text { Cat\#: sc66036 }\end{array}$ \\
\hline $\begin{array}{l}\text { Anti-beta Actin } \\
\text { ( } \beta \text { actin })\end{array}$ & 43 & $\begin{array}{l}\text { Mouse monoclonal anti-Beta } \\
\text { actin (Bactin) Clone AC-15 }\end{array}$ & $\begin{array}{l}\text { Sigma Aldrich } \\
\text { Cat\#: A1978 }\end{array}$ \\
\hline Anti-GAPDH & 37 & $\begin{array}{r}\text { Mouse monoclonal anti-GAPDH } \\
\text { Clone GAPDH-71.1( } \mathbf{W B})\end{array}$ & $\begin{array}{l}\text { Sigma-Aldrich } \\
\text { Cat\#: G8795 }\end{array}$ \\
\hline Anti-p62 & 62 & $\begin{array}{l}\text { Rabbit polyclonal anti- } \\
\text { p62/SQSTM1 (WB) }\end{array}$ & $\begin{array}{l}\text { Sigma Aldrich } \\
\text { Cat\#: P0067 }\end{array}$ \\
\hline Anti-4HNE & N/A & $\begin{array}{c}\text { Mouse monoclonal anti-4 HNE } \\
\text { (HNEJ-2) (IHC) }\end{array}$ & $\begin{array}{c}\text { Abcam } \\
\text { Cat\#: ab48506 }\end{array}$ \\
\hline Anti-NQO1 & 28 & $\begin{array}{c}\text { Rabbit polyclonal anti-NQO1(C- } \\
\text { terminal) (WB) }\end{array}$ & $\begin{array}{l}\text { Sigma Aldrich } \\
\text { Cat\#: N5288 }\end{array}$ \\
\hline
\end{tabular}

MW, predicted molecular weight; IHC, Immunohistochemistry staining; WB, Western blot analysis 
Online Table 2. Primer information for qPCR

\begin{tabular}{|c|c|c|c|c|}
\hline Primers & Gene access \# & Forward $(5,-3$ ') & Reverse (5'-3') & Product \\
\hline \multicolumn{5}{|l|}{ mouse } \\
\hline Acs14 & NM_207625.2 & $\begin{array}{l}\text { AGAGTCCAAAGCGA } \\
\text { GGGAGA }\end{array}$ & $\begin{array}{l}\text { TCTCTCCAGTTCCCA } \\
\text { AACGC }\end{array}$ & 152 \\
\hline Agt & NM_007428.4 & $\begin{array}{l}\text { CGGAGGCAAATCTG } \\
\text { AACAACAT }\end{array}$ & $\begin{array}{l}\text { ACAAGGCCTCACAC } \\
\text { CACACTCT }\end{array}$ & 250 \\
\hline $\operatorname{Atg} 5$ & NM_001358596.1 & $\begin{array}{l}\text { GGTTCCGAGGGCGG } \\
\text { AAGTGC }\end{array}$ & $\begin{array}{l}\text { CGGTCGGGTTCTGTC } \\
\text { TGCCG }\end{array}$ & 134 \\
\hline $\operatorname{Atg} 7$ & NM_001253717.1 & $\begin{array}{l}\text { GTTGAGCGGCGACA } \\
\text { GCATTA }\end{array}$ & $\begin{array}{l}\text { GGAAAGCCTCATGG } \\
\text { CAGGAA }\end{array}$ & 133 \\
\hline Atg12 & NM_026217.3 & $\begin{array}{l}\text { CCACAGCCCATTTCT } \\
\text { TTGTT }\end{array}$ & $\begin{array}{l}\text { GAAACAGCCACCCC } \\
\text { AGAG }\end{array}$ & 145 \\
\hline Atg16L1 & NM_001205392.1 & $\begin{array}{l}\text { GCAGCAAAGGAACC } \\
\text { TCTACCT }\end{array}$ & $\begin{array}{l}\text { AGTTGGGACTCTCA } \\
\text { CATCTTACC }\end{array}$ & 201 \\
\hline $\mathrm{Cd} 36$ & NM_001159557.1 & $\begin{array}{l}\text { CTAGCTGATTACTTC } \\
\text { TGTGTACTGC }\end{array}$ & $\begin{array}{l}\text { TACGTGGCCCGGTTC } \\
\text { TAATTCA }\end{array}$ & 183 \\
\hline Cox 2 & AF378830.1 & $\begin{array}{l}\text { AACCGAGTCGTTCT } \\
\text { GCCAAT }\end{array}$ & $\begin{array}{l}\text { ATTTAGTCGGCCTGG } \\
\text { GATGG }\end{array}$ & 123 \\
\hline Fgf 21 & NM_020013.4 & $\begin{array}{l}\text { GCATACCCCATCCCT } \\
\text { GACTC }\end{array}$ & $\begin{array}{l}\text { AGGTGGGCTTCAGT } \\
\text { GTCTTG }\end{array}$ & 101 \\
\hline Fpn1 & NM_016917.2 & $\begin{array}{l}\text { CTCCAGTCATTGGCT } \\
\text { GTGGT }\end{array}$ & $\begin{array}{l}\text { TTTTACAGCCAGAG } \\
\text { CAGGGG }\end{array}$ & 110 \\
\hline $\begin{array}{l}\text { Fsp1/Aif } \\
\mathrm{m} 2\end{array}$ & NM_153779.2 & $\begin{array}{l}\text { CTTACAAGCCAGAG } \\
\text { ACTGACCA } \\
\end{array}$ & $\begin{array}{l}\text { AGGCCTGTCACTGA } \\
\text { AGAGTC }\end{array}$ & 167 \\
\hline Fth1 & NM_010239.2 & $\begin{array}{l}\text { CTGGAACTGCACAA } \\
\text { ACTGGC }\end{array}$ & $\begin{array}{l}\text { CTCTCATCACCGTGT } \\
\text { CCCAG }\end{array}$ & 200 \\
\hline Gapdh & NM_001289726.1 & $\begin{array}{l}\text { GCACAGTCAAGGCC } \\
\text { GAGAAT }\end{array}$ & $\begin{array}{l}\text { GCCTTCTCCATGGTG } \\
\text { GTGAA }\end{array}$ & 151 \\
\hline Gpx4 & NM_001037741.4 & $\begin{array}{l}\text { CCTCTGCTGCAAGA } \\
\text { GCCTCCC }\end{array}$ & $\begin{array}{l}\text { CTTATCCAGGCAGA } \\
\text { CCATGTGC }\end{array}$ & 144 \\
\hline Hamp1 & NM_032541.2 & $\begin{array}{l}\text { CTTTGCACGGGGAA } \\
\text { GAAAGC }\end{array}$ & $\begin{array}{l}\text { GCAACAGATACCAC } \\
\text { ACTGGGA }\end{array}$ & 131 \\
\hline Hol & NM_010442.2 & $\begin{array}{l}\text { TGACACCTGAGGTC } \\
\text { AAGCAC }\end{array}$ & $\begin{array}{l}\text { GTCTCTGCAGGGGC } \\
\text { AGTATC }\end{array}$ & 184 \\
\hline Klf9 & NM_010638.5 & $\begin{array}{l}\text { GCCGCCTACATGGA } \\
\text { CTTCG }\end{array}$ & $\begin{array}{l}\text { GGTCACCGTGTTCCT } \\
\text { TGGT }\end{array}$ & 139 \\
\hline Lamp1 & NM_001317353.1 & $\begin{array}{l}\text { TAGTGCCCACATTCA } \\
\text { GCATCTCCA }\end{array}$ & $\begin{array}{l}\text { TCCTGCCAATGAGG } \\
\text { TAGGCAATGA }\end{array}$ & 282 \\
\hline Lamp2 & NM_010685.4 & $\begin{array}{l}\text { GGTGCTGGTCTTTCA } \\
\text { GGCTTGATT }\end{array}$ & $\begin{array}{l}\text { ACCACCCAATCTAA } \\
\text { GAGCAGGACT }\end{array}$ & 198 \\
\hline
\end{tabular}




\begin{tabular}{|c|c|c|c|c|}
\hline NQO1 & NM_008706.5 & $\begin{array}{l}\text { AGGGCAGAAGGGAA } \\
\text { TTGCTC }\end{array}$ & $\begin{array}{l}\text { AAAGAGCTGGAGAG } \\
\text { CCAACC }\end{array}$ & 154 \\
\hline Nrf2 & NM_010902.4 & $\begin{array}{l}\text { CCTAGGTCCTTGTTC } \\
\text { CGCC }\end{array}$ & $\begin{array}{l}\text { CTAGTCCGAGCAGC } \\
\text { GGAGA }\end{array}$ & 105 \\
\hline Rab9 & NM_019773.2 & $\begin{array}{l}\text { AGGACGTCCAGTGT } \\
\text { GTGTCT }\end{array}$ & $\begin{array}{l}\text { GTGTGGAAGAGCTG } \\
\text { GGAATCA }\end{array}$ & 199 \\
\hline Rab7 & NM_001293652.1 & $\begin{array}{l}\text { GGCCGGAGCTTTGA } \\
\text { CCATAA }\end{array}$ & $\begin{array}{l}\text { AACAGAGACGTCCG } \\
\text { ATTCCG }\end{array}$ & 105 \\
\hline TFR1 & NM_011638.4 & $\begin{array}{l}\text { AAGTGACGTAGATC } \\
\text { CAGAGGG }\end{array}$ & $\begin{array}{l}\text { AGTACTAGGAAGCG } \\
\text { CCTCTACA }\end{array}$ & 136 \\
\hline \multicolumn{5}{|l|}{ Rat } \\
\hline Acsl4 & NM_053623.1 & $\begin{array}{l}\text { CTCTCCGGGAGCTTC } \\
\text { CTTCC }\end{array}$ & $\begin{array}{l}\text { GCGTGACAGAGCGA } \\
\text { TATGGA }\end{array}$ & 196 \\
\hline Agt & NM_134432.2 & $\begin{array}{l}\text { GCTGGAGCTAAAGG } \\
\text { ACACACA }\end{array}$ & $\begin{array}{l}\text { GATGTATACGCGGT } \\
\text { CCCCAG }\end{array}$ & 130 \\
\hline $\operatorname{Atg} 5$ & NM_001014250.1 & $\begin{array}{l}\text { AGCCTCTCTTCTCGG } \\
\text { GAACT }\end{array}$ & $\begin{array}{l}\text { GTTTCCACTCTCCAG } \\
\text { CCGAA }\end{array}$ & 141 \\
\hline $\mathrm{Cd} 36$ & NM_031561.2 & $\begin{array}{l}\text { GTACTCTCTCCTCGG } \\
\text { ATGGC }\end{array}$ & $\begin{array}{l}\text { TGCTTTCTATGTGGC } \\
\text { CTGGT }\end{array}$ & 158 \\
\hline Chac1 & NM_001173437.1 & $\begin{array}{l}\text { CAGACACAGCATCC } \\
\text { CCATGT }\end{array}$ & $\begin{array}{l}\text { TGTGGGTCAACGGA } \\
\text { GAACAG }\end{array}$ & 139 \\
\hline $\operatorname{Cox} 2$ & S67722.1 & $\begin{array}{l}\text { TGACTTTGGCAGGCT } \\
\text { GGATT }\end{array}$ & $\begin{array}{l}\text { ACTGCACTTCTGGTA } \\
\text { CCGTG }\end{array}$ & 139 \\
\hline $\begin{array}{l}\text { Fsp1/Aif } \\
\mathrm{m} 2\end{array}$ & NM_001139483.1 & $\begin{array}{l}\text { AAGCATTGGGCTTT } \\
\text { GGGAGT }\end{array}$ & $\begin{array}{l}\text { GCCCCAGTTAATCCC } \\
\text { TGCAT }\end{array}$ & 166 \\
\hline Fth1 & NM_012848.2 & $\begin{array}{l}\text { CTTTGCAACTTCGTC } \\
\text { GCTCC }\end{array}$ & $\begin{array}{l}\text { GTCCTGGTGGTAGTT } \\
\text { CTGGC }\end{array}$ & 109 \\
\hline Ftl1 & NM_022500.4 & $\begin{array}{l}\text { GCTCCATACTCCGG } \\
\text { ATCAGC }\end{array}$ & $\begin{array}{l}\text { AGCCCAGAGAGAGG } \\
\text { TAGGTG }\end{array}$ & 127 \\
\hline Hamp1 & NM_053469.1 & $\begin{array}{l}\text { TCTCCTGCTTCTCCT } \\
\text { CCTGG }\end{array}$ & $\begin{array}{l}\text { TCAGCAGCGCACTG } \\
\text { TCATC }\end{array}$ & 125 \\
\hline Gapdh & NM_017008.4 & $\begin{array}{l}\text { TCTCTGCTCCTCCCT } \\
\text { GTTCT }\end{array}$ & $\begin{array}{l}\text { TACGGCCAAATCCG } \\
\text { TTCACA }\end{array}$ & 104 \\
\hline Gpx4 & NM_001039849.3 & $\begin{array}{l}\text { GGGGACGCTGCAGA } \\
\text { CAG }\end{array}$ & $\begin{array}{l}\text { CGAGCTCTCCTCCTC } \\
\text { CGA }\end{array}$ & 106 \\
\hline Klf9 & NM_057211.1 & $\begin{array}{l}\text { ATAACAACGCCACT } \\
\text { CACGGG }\end{array}$ & $\begin{array}{l}\text { ACCAAAAGGGGGCA } \\
\text { TTTCCA }\end{array}$ & 113 \\
\hline NQO1 & NM_017000.3 & $\begin{array}{l}\text { GGCATCCAATCCTCC } \\
\text { ACCC }\end{array}$ & $\begin{array}{l}\text { AATCCCCCGAGGCT } \\
\text { TGTCA }\end{array}$ & 175 \\
\hline Nrf2 & NM_031789.2 & $\begin{array}{l}\text { GGTTGCCCACATTCC } \\
\text { CAAAC }\end{array}$ & $\begin{array}{l}\text { GGCTGGGAATATCC } \\
\text { AGGGC }\end{array}$ & 116 \\
\hline TfR1 & NM_022712.1 & $\begin{array}{l}\text { TGCTTCAGAGTGCTC } \\
\text { CCTTG }\end{array}$ & $\begin{array}{l}\text { ACTTGCCGAGCAAG } \\
\text { GCTAAA }\end{array}$ & 117 \\
\hline
\end{tabular}


Online Table 3. Metabolic profile of type 1 diabetic mice. Type 1 diabetes (T1D) in female wild type FVB/N mice at age of 8 9 weeks was induced as described in "Research Design and Methods" Fasting blood glucose as well as non-fasting triglyceride and cholesterol were measured at indicated time points. ${ }^{*}, p<0.05$ vs. time 0 in the same groups, $\#, p<0.05$ vs. 3 months in the same groups.

\begin{tabular}{|c|c|c|c|c|c|c|}
\hline & \multicolumn{3}{|c|}{ Ctl (Veh) } & \multicolumn{3}{c|}{ T1D (STZ) } \\
\hline $\begin{array}{c}\text { Time } \\
(\text { months })\end{array}$ & 0 & 3 & 6 & 0 & 3 & 6 \\
\hline$(\mathrm{n})$ & $(\mathrm{n}=3)$ & $(\mathrm{n}=3)$ & $(\mathrm{n}=3)$ & $(\mathrm{n}=4)$ & $(\mathrm{n}=4)$ & $(\mathrm{n}=3)$ \\
\hline $\begin{array}{c}\text { Glucose } \\
(\mathrm{mmol} / \mathrm{L})\end{array}$ & $4.9 \pm 0.5$ & $4.8 \pm 0.8$ & $5.3 \pm 0.9$ & $5.1 \pm 0.5$ & $23.3 \pm 1.9^{*}$ & $24.0 \pm 2.0^{*}$ \\
\hline HbA1C (\%) & $4.9 \pm 0.3$ & $4.7 \pm 0.5$ & $4.9 \pm 0.5$ & $4.8 \pm 0.3$ & $16.2 \pm 1.2^{*}$ & $16.7 \pm 1.3^{*}$ \\
\hline $\begin{array}{c}\text { Triglyceride } \\
(\mathrm{mg} / \mathrm{dl})\end{array}$ & $112.7 \pm 9.7$ & $113.5 \pm 19.4$ & $120.7 \pm 46.2$ & $115.6 \pm 9.0$ & $184.5 \pm 7.4^{*}$ & $258.3 \pm 7.2^{*}, \#$ \\
\hline $\begin{array}{c}\text { Cholesterol } \\
(\mathrm{mg} / \mathrm{dl})\end{array}$ & $102.1 \pm 8.2$ & $115.2 \pm 38.3$ & $121.7 \pm 33.9$ & $103.6 \pm 10.7$ & $153.7 \pm 15.8^{*}$ & $222 \pm 14.3^{*}, \#$ \\
\hline
\end{tabular}




\section{Supplementary Figures and Figure Legends}

A Male (ð) Animal numbers

\begin{tabular}{|l|l|c|c|c|c|c|}
\hline \multicolumn{2}{|c|}{ T1D (Months) } & 0 & 1 & 3 & 6 & 9 \\
\hline \multirow{2}{*}{ Ctl } & Veh & 36 & 35 & 35 & 34 & 33 \\
\cline { 2 - 7 } & STZ & 81 & 63 & 57 & 47 & 35 \\
\hline \multirow{2}{*}{ Nrf2KO } & Veh & 42 & 42 & 41 & 40 & 39 \\
\cline { 2 - 7 } & STZ & 112 & 81 & 57 & 39 & 25 \\
\hline
\end{tabular}

C §

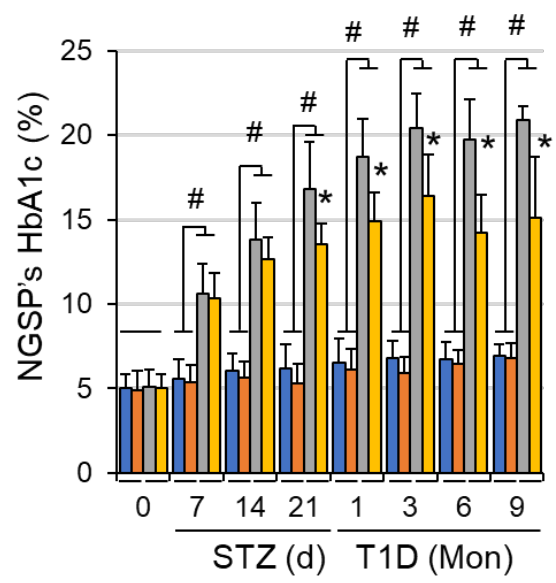

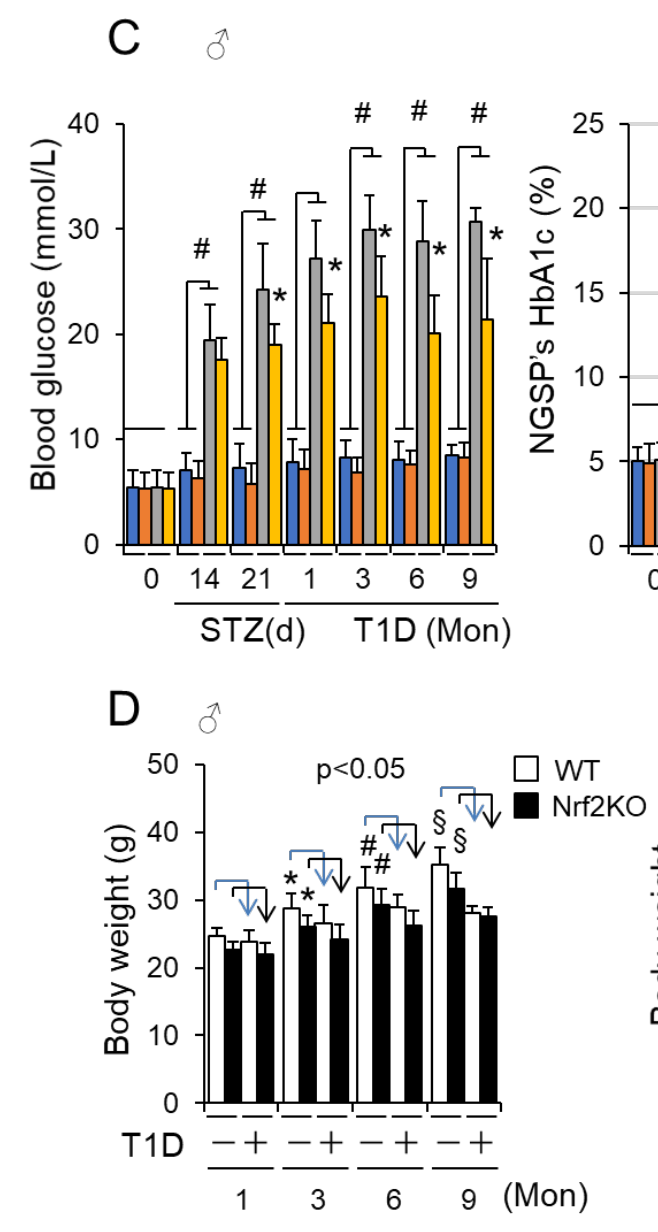

B

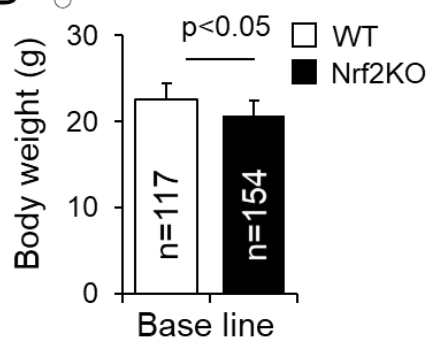

Base line

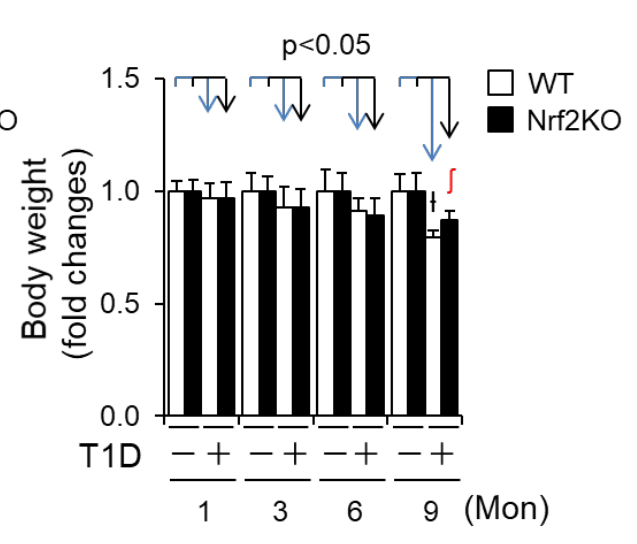

Supplementary Fig. 1. The impact of global knockout of Nrf2 on STZ-induced type 1 diabetes in male mice. Type 1 diabetes (T1D) in adult littermates of male ( $\left.{ }^{\lambda}\right)$ WT control (Ctl) and Nrf2KO mice in a C57BL/6J genetic background was induced by i.p. injection of STZ for 9 months (Mon) as described in "Research Design and Methods". A: Survived animal numbers of each group at each experimental end point. $B$ : Body weights of WT and Nrf2KO mice at the basal condition. $C$ : Fasting blood glucose levels and NGSP's HbA1c (\%). ${ }^{*} p<0.05$ vs. WT STZ groups. \#, $p<0.05$ between indicated groups at each end point. $D$ : Body weight changes of WT and $\mathrm{Nrf2KO}$ mice after onset of T1D. Left panel shows arbitrary $g$ and right panel shows fold changes. ${ }^{*}, p<0.05$ vs. vehicle treated STZ (-) group at $1 \mathrm{Mon}$; \#, $p<0.05$ vs. vehicle treated 
STZ (-) group at 3 Mon; $\S, p<0.05$ vs. vehicle treated STZ (-) group at 6 Mon; $\mathrm{t}, p<0.05$ vs. STZ treated WT group at 6 Mon; $\int, p<0.05$ vs. STZ treated WT group at 9 Mon.
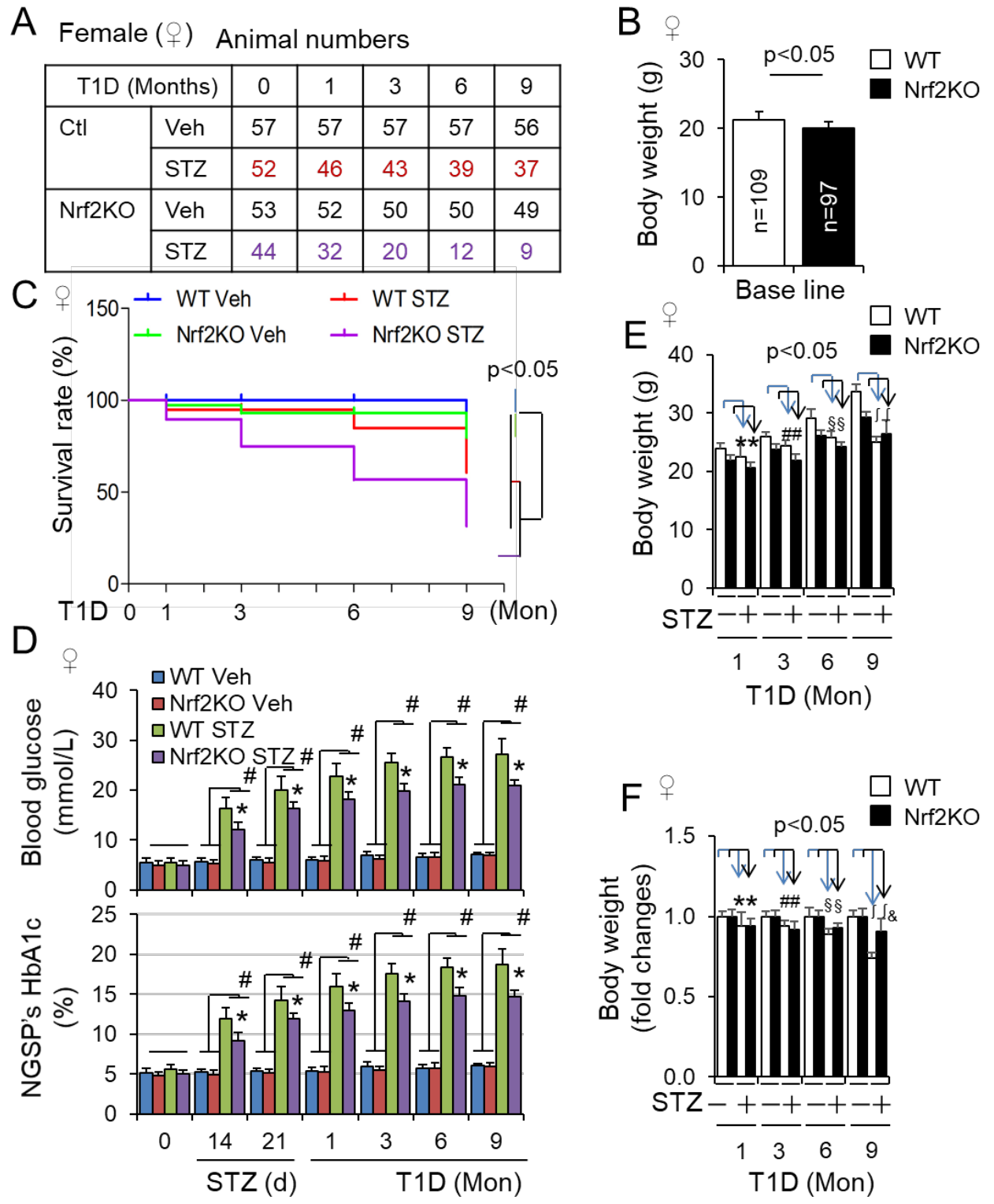

Supplementary Fig. 2. The impact of global knockout of Nrf2 on STZ-induced type 1 diabetes in female mice. Type 1 diabetes (T1D) in adult littermates of female ( + ) WT control (Ctl) and Nrf2KO mice in a C57BL/6J genetic background was induced by i.p. injection of STZ for 9 months (Mon) as described in "Research Design and Method". A: Survived animal numbers of each group at each experimental end point. $B$ : Body weights WT and Nrf2KO mice at the basal condition. $C$ : Kaplan Meier analysis of survival rates. $D$ : Fasting blood glucose levels and NGSP's HbA1C (\%). * $p<0.05$ vs. WT STZ groups. \#, $p<0.05$ between indicated groups at each end point. $E, F$ : Body weight changes $(E, \mathrm{~g})$ and $(F$, fold changes) of WT and Nrf2KO mice after onset of T1D. *,$p<0.05$ vs. vehicle treated STZ (-) group at 1 Mon; \#, $p<0.05$ vs. STZ (-) 
group (+) at 3 Mon; $\S, p<0.05$ vs. STZ (-) group at $6 \mathrm{Mon} ; \int, p<0.05$ vs. STZ (-) groups at 6 Mon; $\&, p<0.05$ vs. STZ treated WT group at 9 Mon. Nrf2KO was confirmed by Western blot analysis using whole left ventricle (LV) tissue lysates at each end point (Supplementary Fig. 9B).

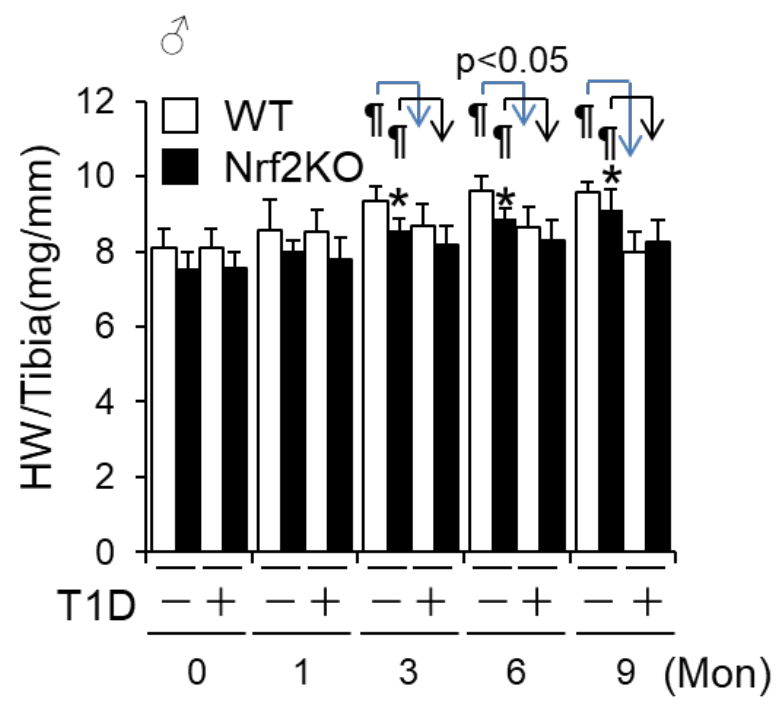

Supplementary Fig. 3. The impact of global knockout of Nrf2 on heart weight (mg) to tibia length $(\mathbf{m m})$ ratios in STZ-induced diabetic male mice. Type 1 diabetes (T1D) was induced by i.p. injection of STZ in littermates of adult male ( $\left.\delta^{\lambda}\right) \mathrm{WT}$ and Nrf2KO mice in a C57BL/6J genetic background for 9 months (Mon) as described in "Research Design and Methods". Heat weight (HW in $\mathrm{mg}$ )/tibia length (Tibia in $\mathrm{mm}$ ) ratios were quantified as described in "Research Design and Methods". \#, $p<0.05$ between indicated groups; *, $p<0.05$ vs. WT STZ group at 9 Mon. Animal numbers for each group are indicated in Supplementary Fig. $1 \mathrm{~A}$ 


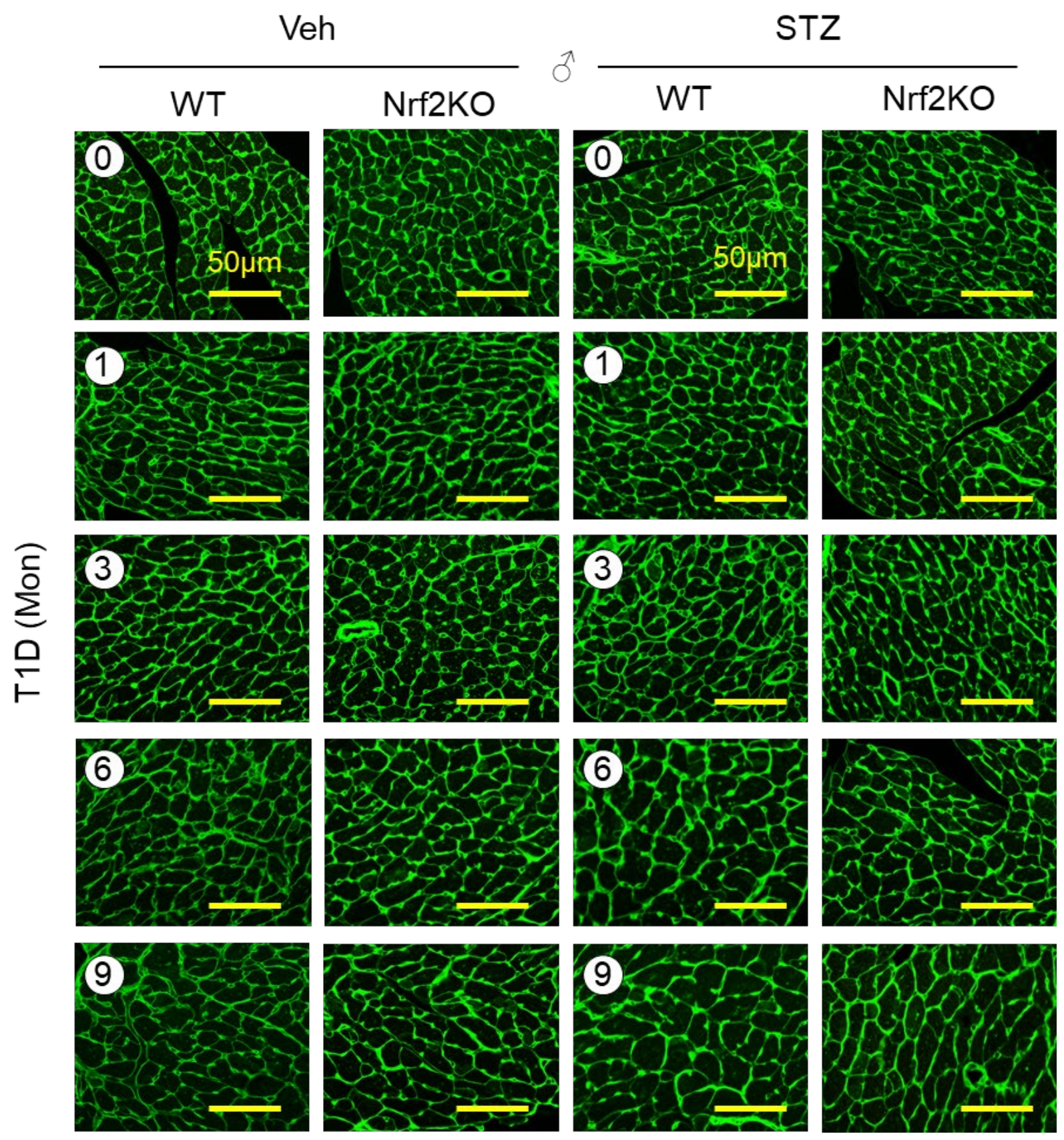

Supplementary Fig. 4. The impact of global knockout of Nrf2 on cardiomyocyte hypertrophy in STZ-induced type 1 diabetic male mice. Type 1 diabetes (T1D) was induced by i.p. injection of STZ in littermates of adult male ( $§) \mathrm{WT}$ and Nrf2KO mice in a C57BL/6J genetic background for 9 months (Mon) as described in "Research Design and Methods". Cardiomyocyte sizes were measured by Wheat Germ Agglutinin (WGA) staining in the left ventricle (LV) tissue sections of male ( $ठ$ ) littermates of WT and Nrf2KO mice at $0,1,3,6,9$ months (Mon) after onset of STZ-induced type 1 diabetes (T1D). The results are representative WGA staining of Fig. $2 B$. Scale bar $=50 \mu \mathrm{m}$. 


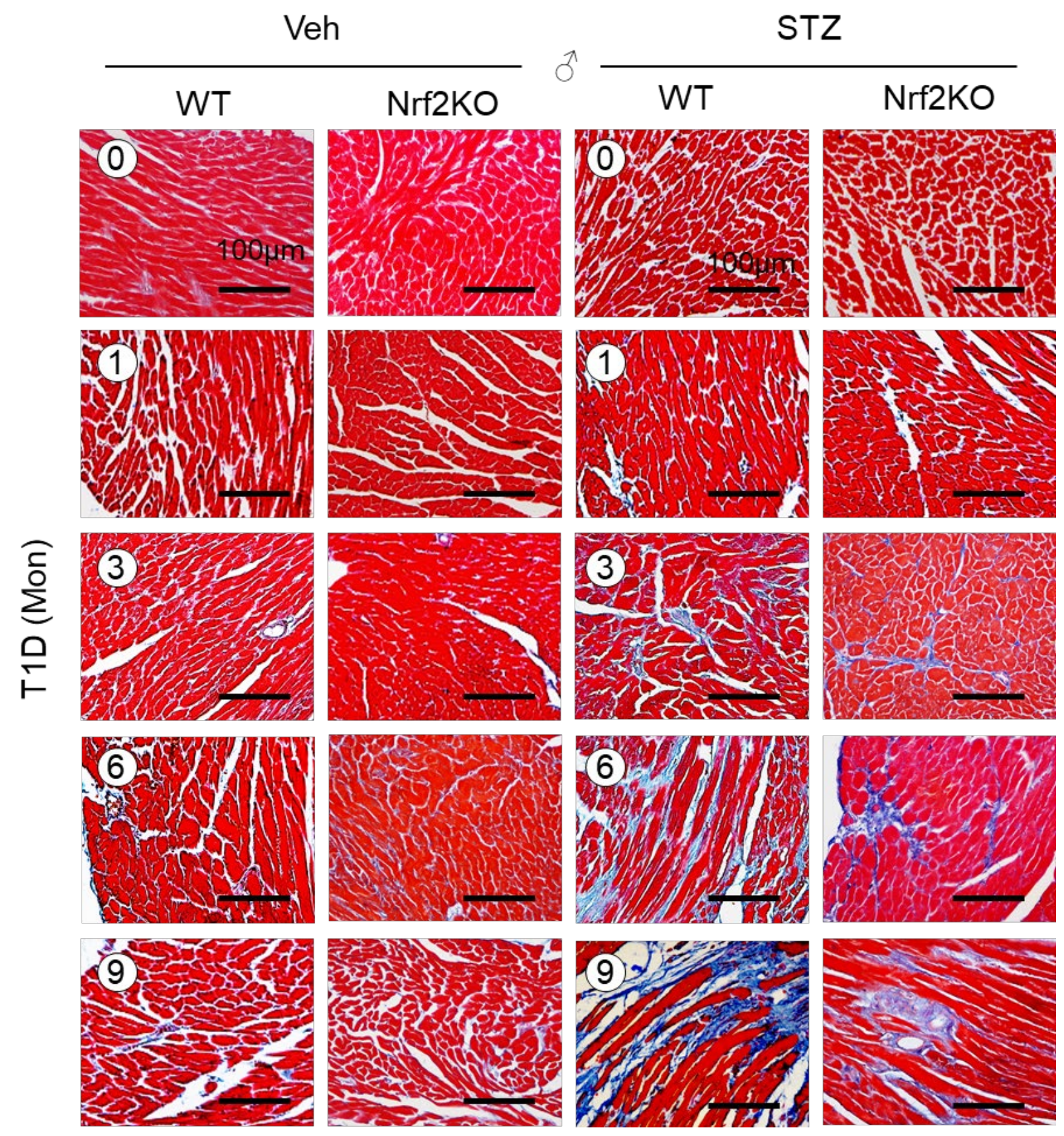

Supplementary Fig. 5. The impact of global knockout of Nrf2 on cardiac fibrosis in STZinduced type 1 diabetic male mice. Type 1 diabetes (T1D) was induced by i.p. injection of STZ in littermates of adult male ( $\lesssim$ ) WT and Nrf2KO mice in a C57BL/6J genetic background for 9 months (Mon) as described in "Research Design and Methods". Cardiac fibrosis (\%) was measured by Masson trichrome staining in in the left ventricle tissue (LV) sections of male ( $\overbrace{}^{\Uparrow})$ littermates of WT and Nrf2KO mice at 0, 1, 3, 6, 9 months (Mon) after onset of STZ-induced type 1 diabetes (T1D). The results are representative Masson trichrome staining of Fig. $2 C$. Scale bar $=100 \mu \mathrm{m}$. 


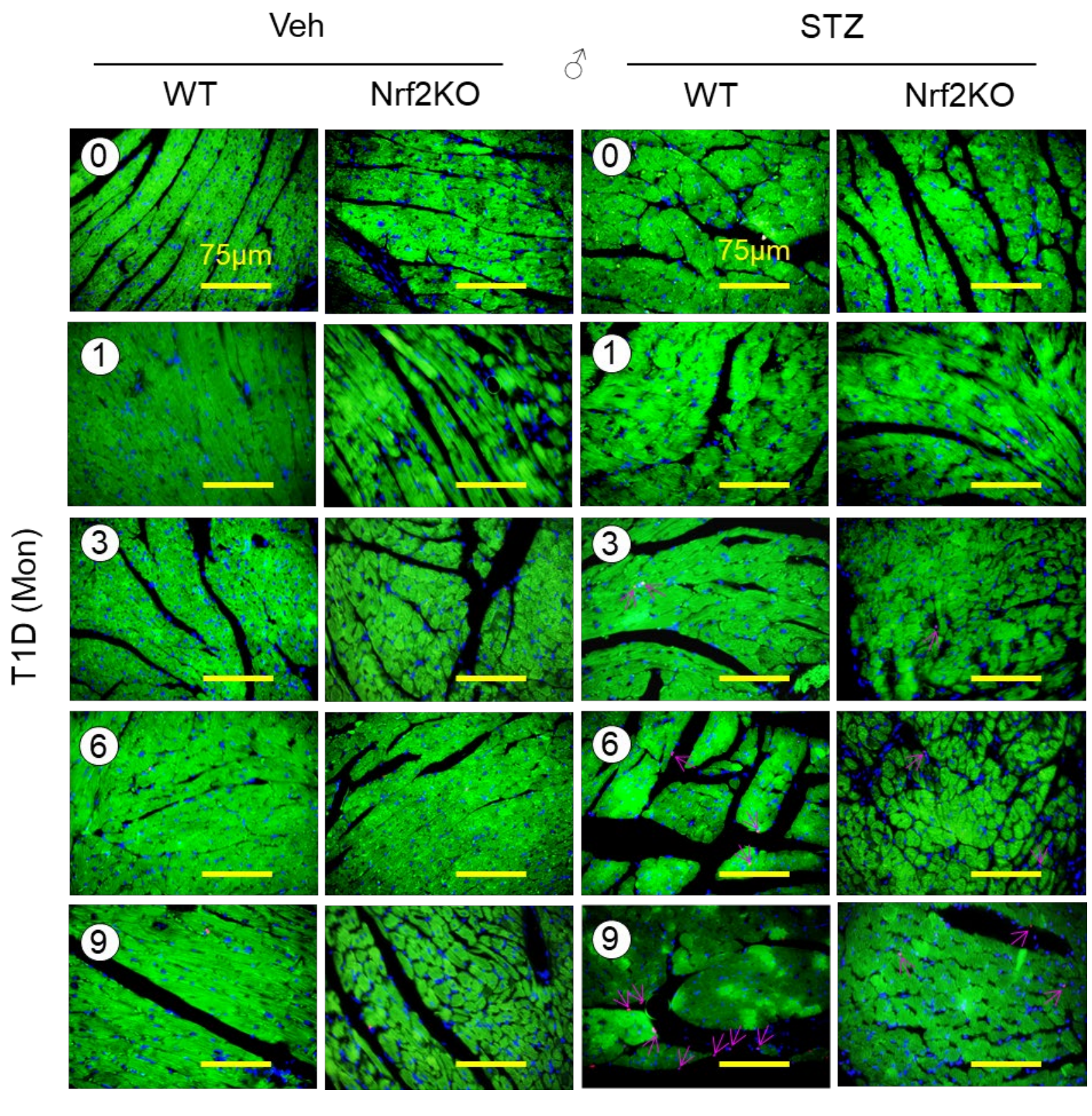

Supplementary Fig. 6. The impact of global knockout of Nrf2 on cardiac apoptosis in STZinduced type 1 diabetic male mice. Type 1 diabetes (T1D) was induced by i.p. injection of STZ in littermates of adult male ( $\left.\delta^{\Uparrow}\right) \mathrm{WT}$ and Nrf2KO mice in a C57BL/6J genetic background for 9 months (Mon) as described in "Research Design and Methods". Cardiac apoptosis (\%) was measured by Tunel staining in the left ventricle (LV) tissue sections of ( $\left.\partial^{\lambda}\right)$ male littermates of WT and Nrf2KO mice at 0, 1, 3, 6, 9 months (Mon) after onset of STZ-induced type 1 diabetes (T1D). Cardiomyocytes (green) were marked by Alexa FluorTM 488 Phalloidin (Invitrogen A12379) binds F-actin. The results are representative Tunel staining of Fig. $2 D$. Scale bar $=75$ $\mu \mathrm{m}$. 


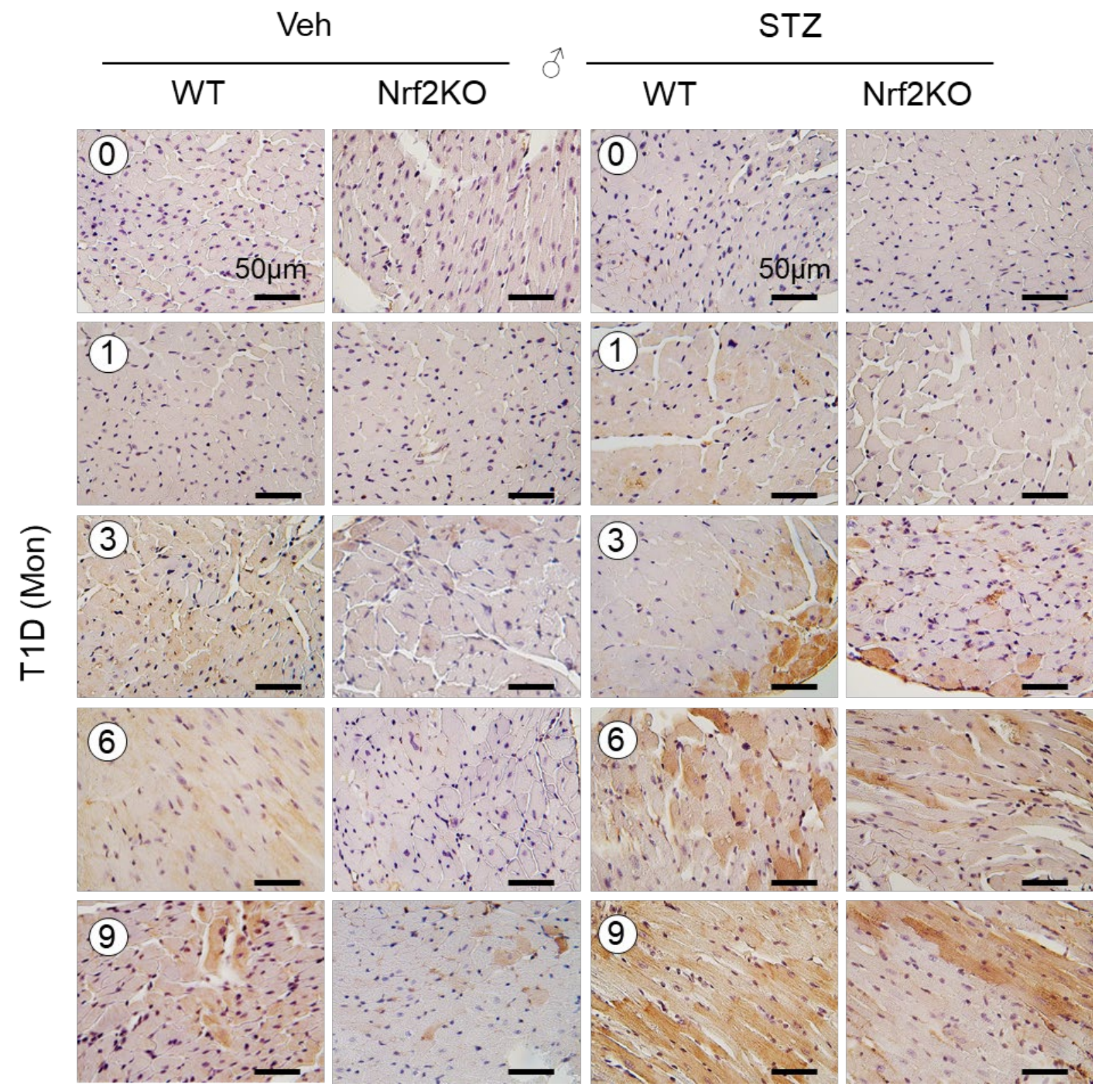

Supplementary Fig. 7. The impact of global knockout of Nrf2 on cardiac lipid peroxidation in STZ-induced type 1 diabetic male mice. Type 1 diabetes (T1D) was induced by i.p. injection of STZ in littermates of adult male ( $\lesssim$ ) WT and Nrf2KO mice in a C57BL/6J genetic background for 9 months (Mon) as described in "Research Design and Methods". Cardiac lipid peroxidation was assessed by quantifying the percentage of 4HNE positively stained areas in the

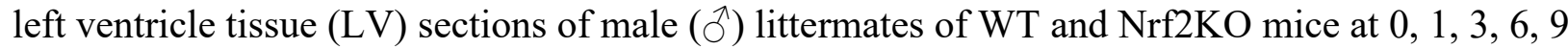
months (Mon) after onset of STZ-induced type 1 diabetes (T1D). The results are representative 4HNE staining of Fig. $2 F$. Scale bar $=50 \mu \mathrm{m}$. 


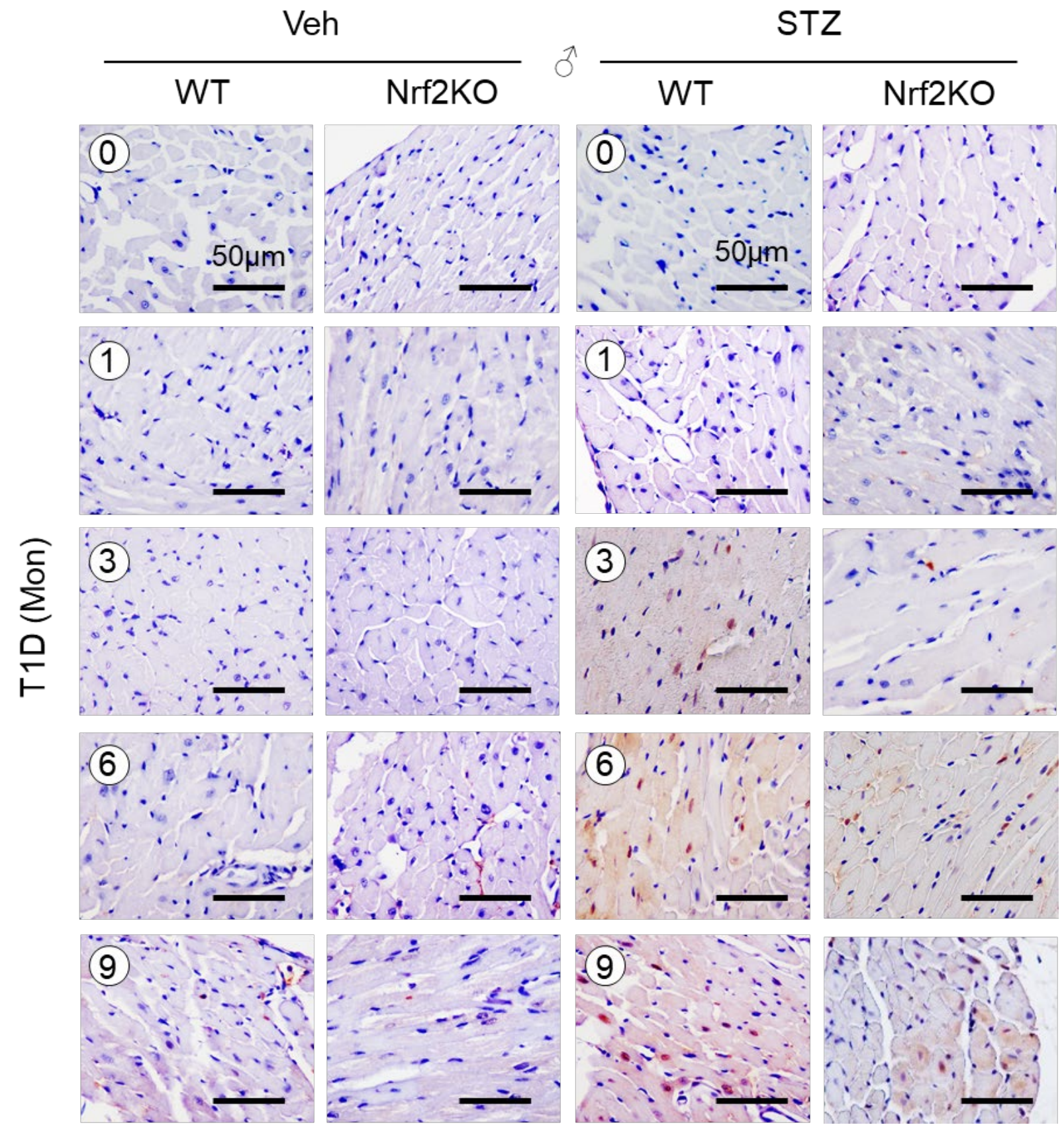

Supplementary Fig. 8. The impact of global knockout of Nrf2 on cardiac oxidative stressinduced DNA damage in STZ-induced type 1 diabetic male mice. Type 1 diabetes (T1D) was induced by i.p. injection of STZ in littermates of adult male ( $\left.{ }^{\lambda}\right) \mathrm{WT}$ and Nrf2KO mice in a C57BL/6J genetic background for 9 months (Mon) as described in "Research Design and Methods". Cardiac oxidative stress-induced DNA damage was assessed by quantifying the percentage of $8 \mathrm{OHdG}$ positively stained nuclei in the left ventricle (LV) tissue sections of male $\left({ }^{\top}\right)$ littermates of WT and Nrf2KO mice at 0, 1, 3, 6, 9 months (Mon) after onset of STZinduced type 1 diabetes (T1D). The results are representative $8 \mathrm{OHdG}$ staining of Fig. $2 F$. Scale bar $=50 \mu \mathrm{m}$. 


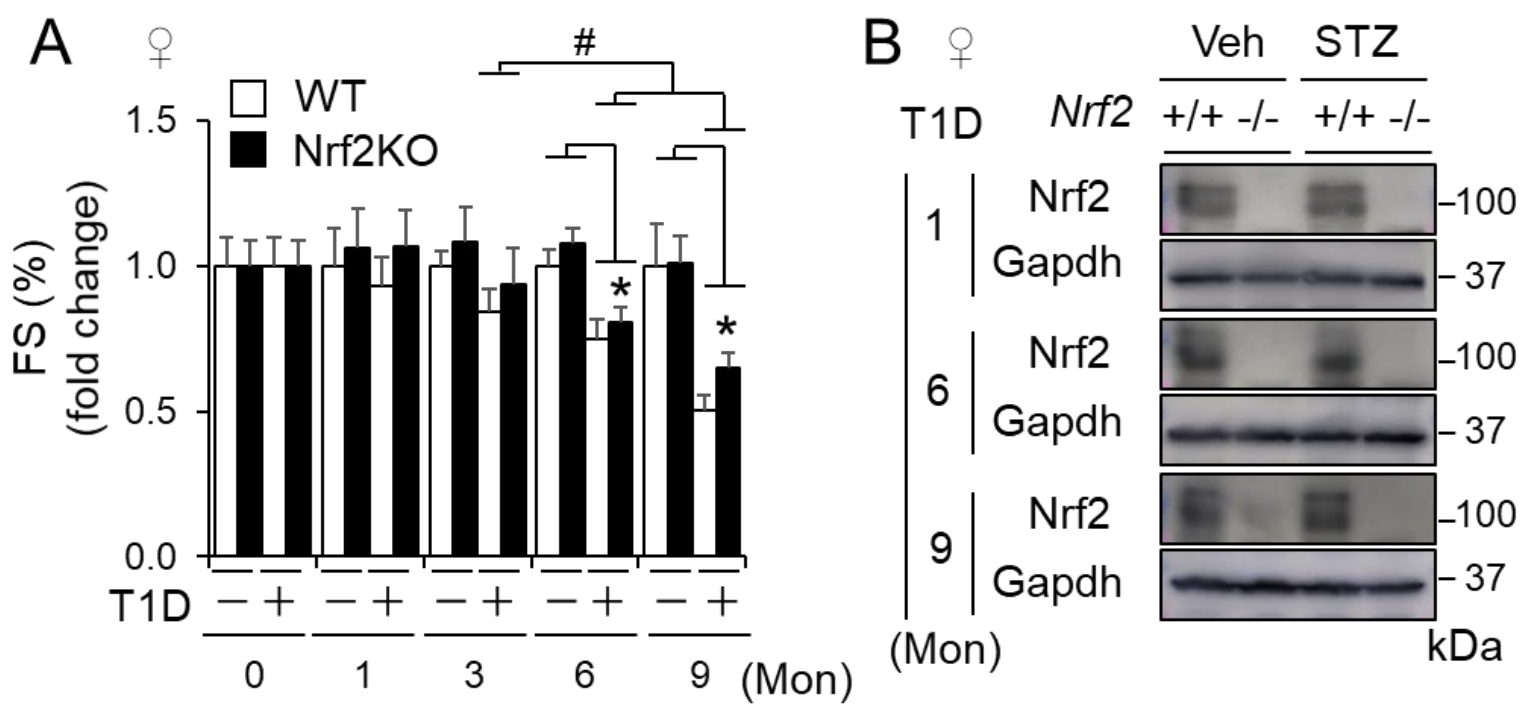

Supplementary Fig. 9. The impact of global knockout of Nrf2 on cardiac function in STZinduced diabetic female mice. Type 1 diabetes (T1D) was induced by i.p. injection of STZ in littermates of adult female ( $(+) \mathrm{WT}$ and Nrf2KO mice in a C57BL/6J genetic background for 9 months (Mon) as described in "Research Design and Methods". Animal numbers for each group are indicated in Supplementary Fig. $2 A$. A: FS (\%). Cardiac function was monitored monthly by echocardiography. ${ }^{*}, p<0.05$ vs. WT STZ group at each time point; $\#, p<0.05$ between indicated groups. $B$ : Representative immunoblots of myocardial Nrf2 at each experimental end point. Western blot analysis was carried out using whole left ventricle (LV) tissue lysates of mice with indicated genotypes. WT, Nrf2+/+; Nrf2KO, Nrf2-/-. 

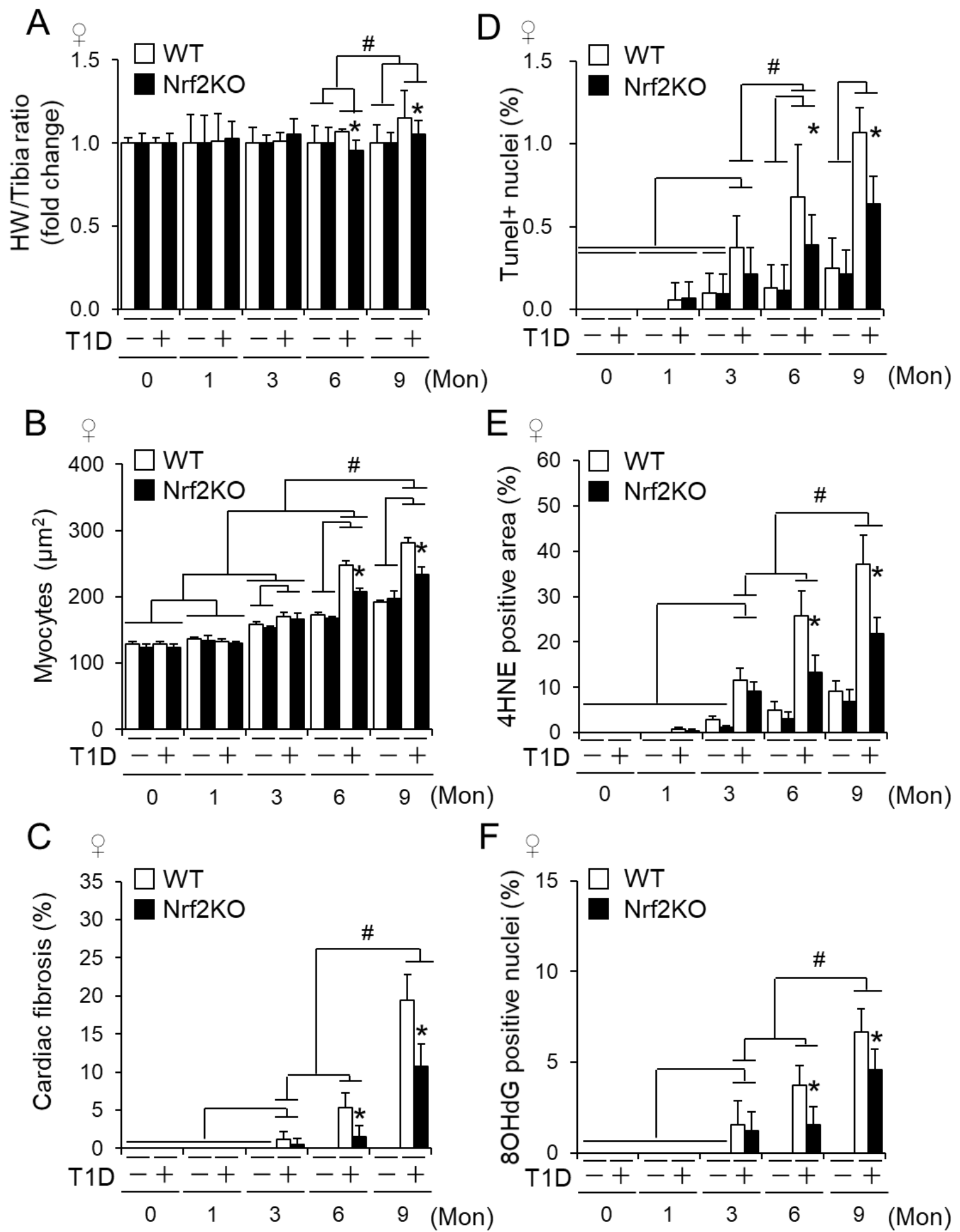

Supplementary Fig. 10. The impact of global knockout of Nrf2 on cardiac remodeling, cell death and oxidative stress in STZ-induced type 1 diabetic female mice. Type 1 diabetes (T1D) in adult littermates of female ( $(+) \mathrm{WT}$ and Nrf2KO mice in a C57BL/6J genetic background was induced by i.p. injection of STZ for 9 months (Mon) and T1D-induced cardiomyopathy was assessed as described in "Research Design and Methods". $A$ : Heat weight 
(HW)/Tibia length ratio in fold changes. The values of vehicle treated groups are set as 1-fold. Animal numbers for each group are indicated in Supplementary Fig. $2 A$. B: Myocyte sizes. $C$ : Cardiac fibrosis (\%). $D$ : Cardiac apoptosis. $E: \& F$ : Cardiac oxidative stress. $B-F$ in left ventricle $(\mathrm{LV})$ tissue sections of the $\mathrm{WT}$ and $\mathrm{Nrf} 2 \mathrm{KO}$ mice $(+)$ with indicated treatments were analyzed. $B-F$ : Animal numbers for each group are 6-8. $B-F$ : \#, $p<0.05$ between indicated groups; ${ }^{*}, p<$ 0.05 vs. STZ treated WT groups at the same end points.

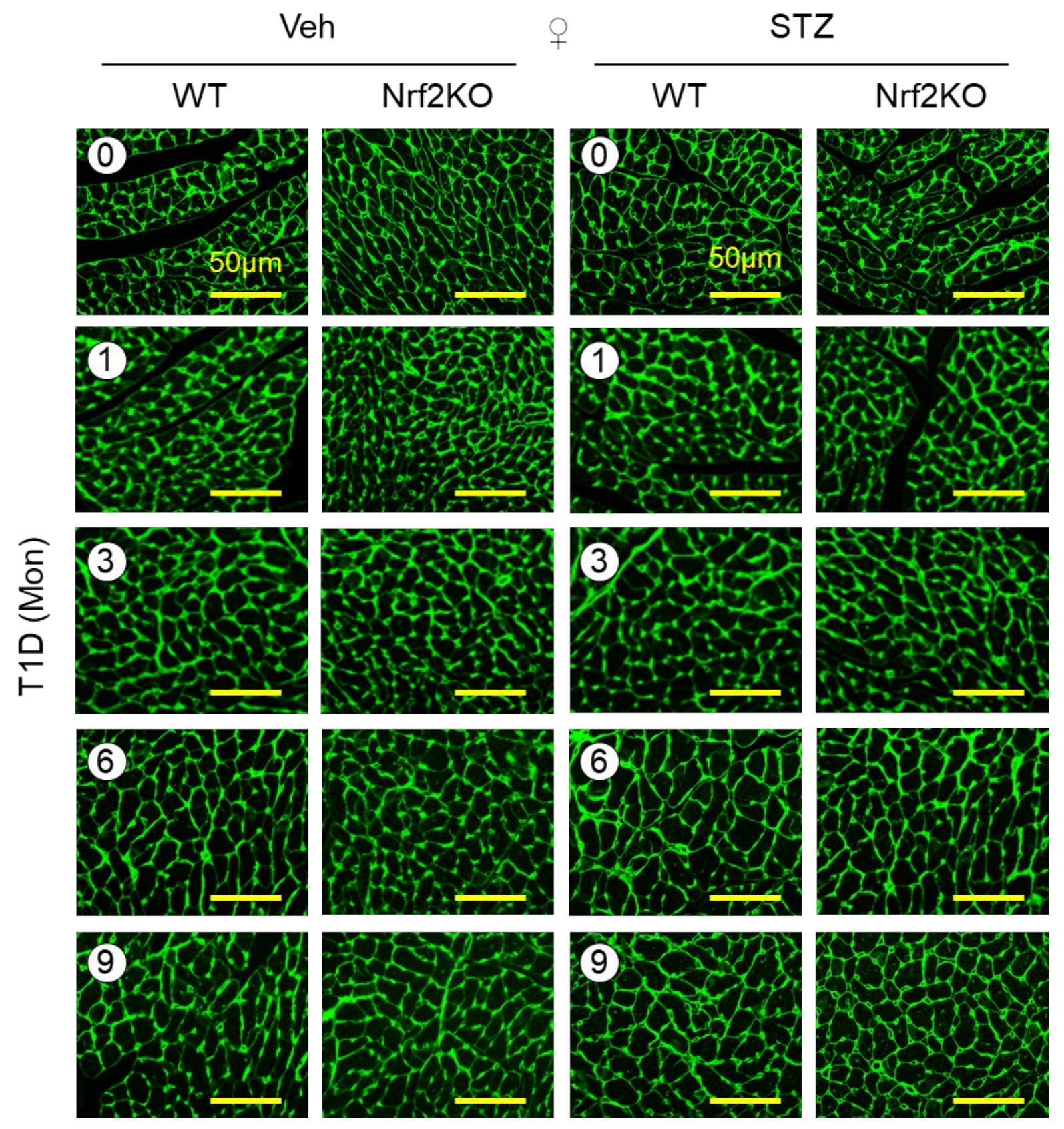

Supplementary Fig. 11. The impact of global knockout of Nrf2 on cardiomyocyte hypertrophy in STZ-induced type 1 diabetic female mice. The results are representative 
Wheat Germ Agglutinin (WGA) staining of Supplementary Fig. 10B showing cardiomyocyte sizes in the left ventricles (LVs) of female ( $(+)$ WT and Nrf2 KO mice at 0, 1, 3, 6, 9 months (Mon) after onset of STZ-induced type 1 diabetes (T1D). Scale bar $=50 \mu \mathrm{m}$.

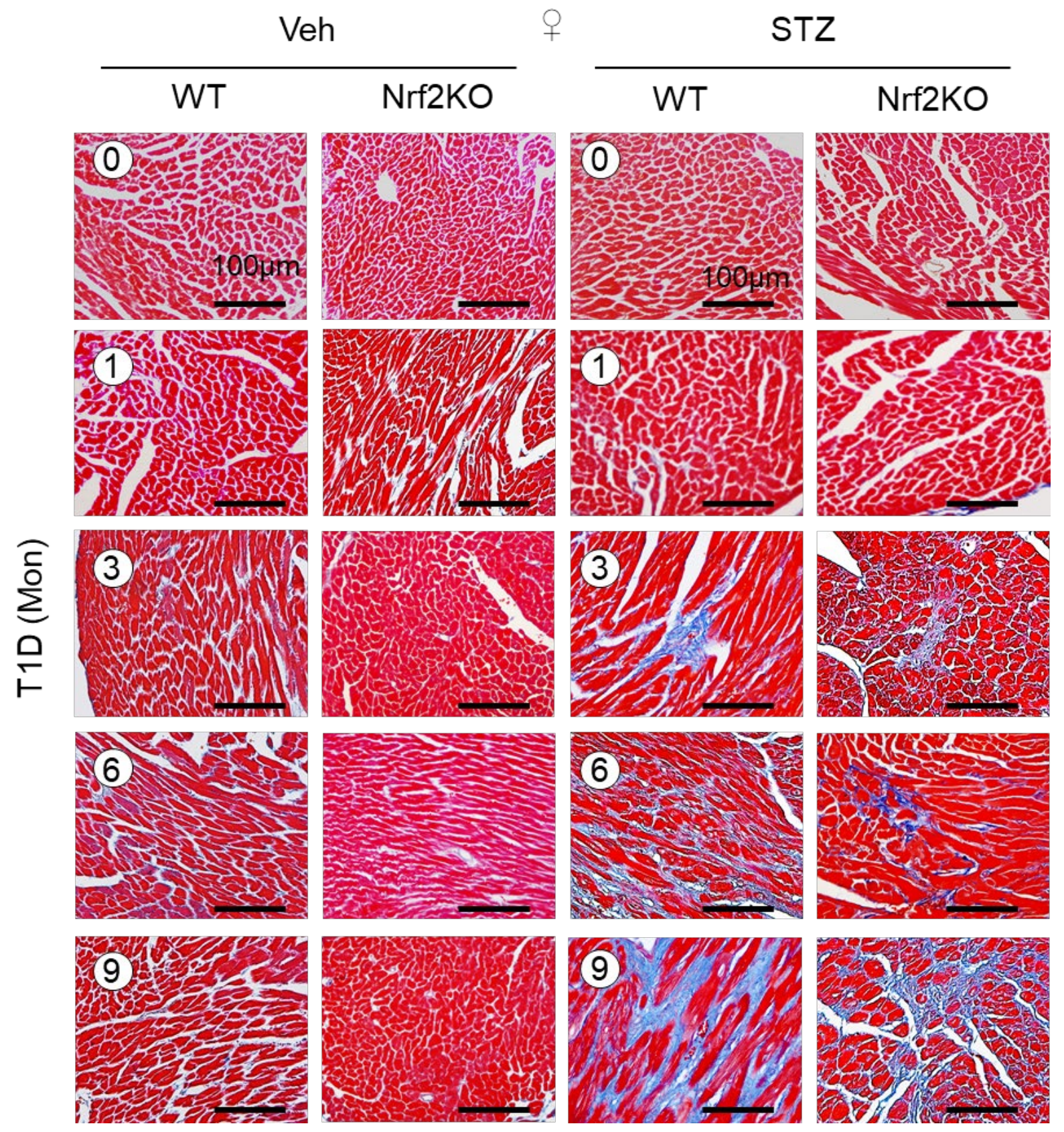

Supplementary Fig. 12. The impact of global knockout of Nrf2 on cardiac fibrosis in STZinduced type 1 diabetic female mice. The results are representative Masson trichrome staining of Supplementary Fig. 10C showing cardiac fibrosis (\%) in the left ventricles (LVs) of female (ㅇ) of WT and Nrf2KO mice at 0, 1, 3, 6, 9 months (Mon) after onset of STZ-induced type 1 diabetes (T1D). Scale bar $=100 \mu \mathrm{m}$. 

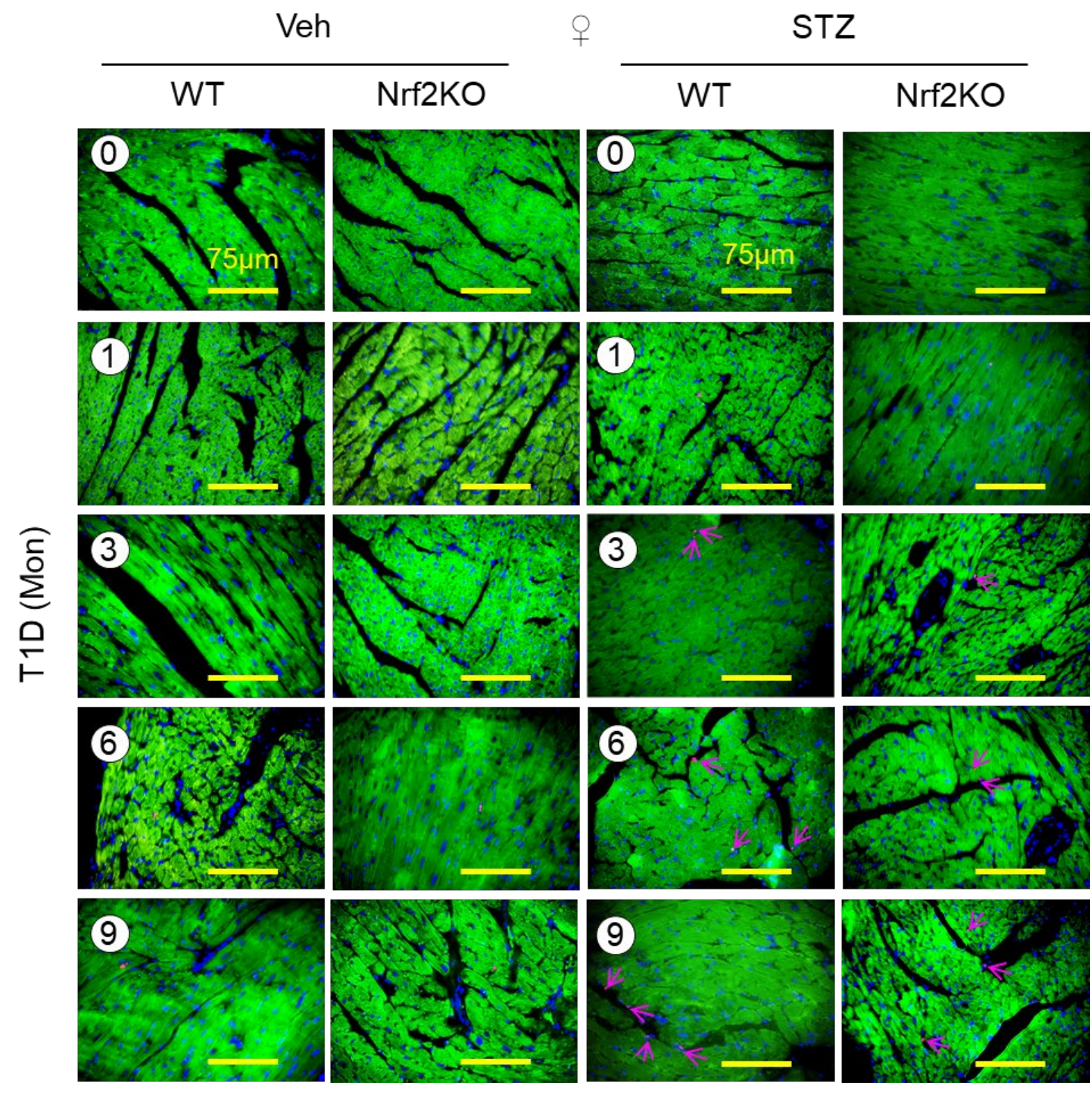

Supplementary Fig. 13. The impact of global knockout of Nrf2 on cardiac apoptosis in STZ-induced type 1 diabetic female mice. The results are representative Tunel staining of Supplementary Fig. 10D showing apoptosis (\%) in the left ventricles (LVs) of female (\%) WT and Nrf2KO mice at 0, 1, 3, 6, 9 months (Mon) after onset of STZ-induced type 1 diabetes (T1D). Cardiomyocytes (green) were marked by Alexa FluorTM 488 Phalloidin (Invitrogen A12379) binds F-actin. Scale bar $=75 \mu \mathrm{m}$. 


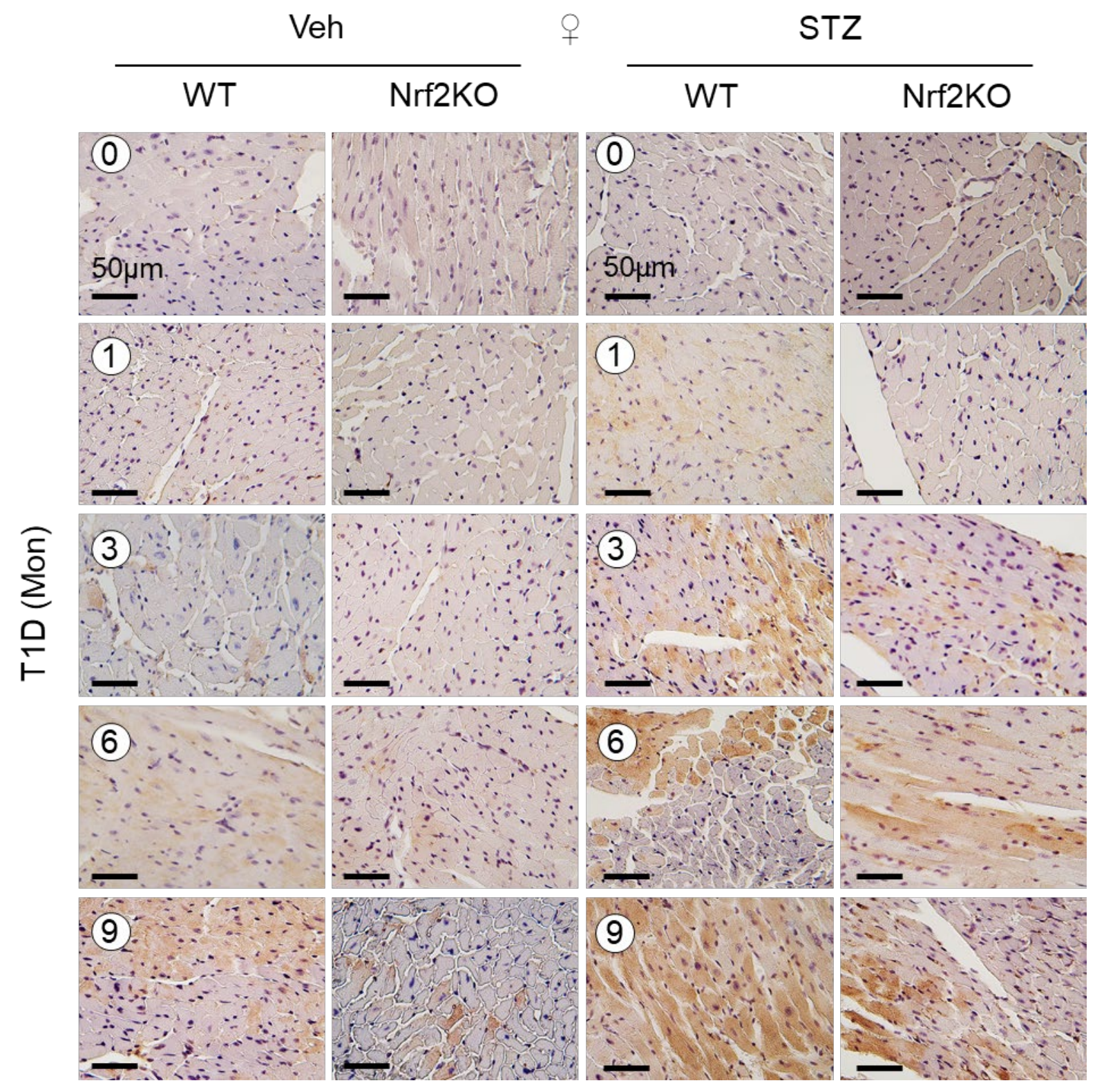

\section{Supplementary Fig. 14. The impact of global knockout of Nrf2 on cardiac lipid}

peroxidation in STZ-induced type 1 diabetic female mice. The results are representative 4HNE staining of Supplementary Fig. 10E showing lipid peroxidation in the left ventricles (LVs) of female () WT and Nrf2KO mice at 0, 1, 3, 6, 9 months (Mon) after onset of STZ-induced type 1 diabetes (T1D). Scale bar $=50 \mu \mathrm{m}$. 


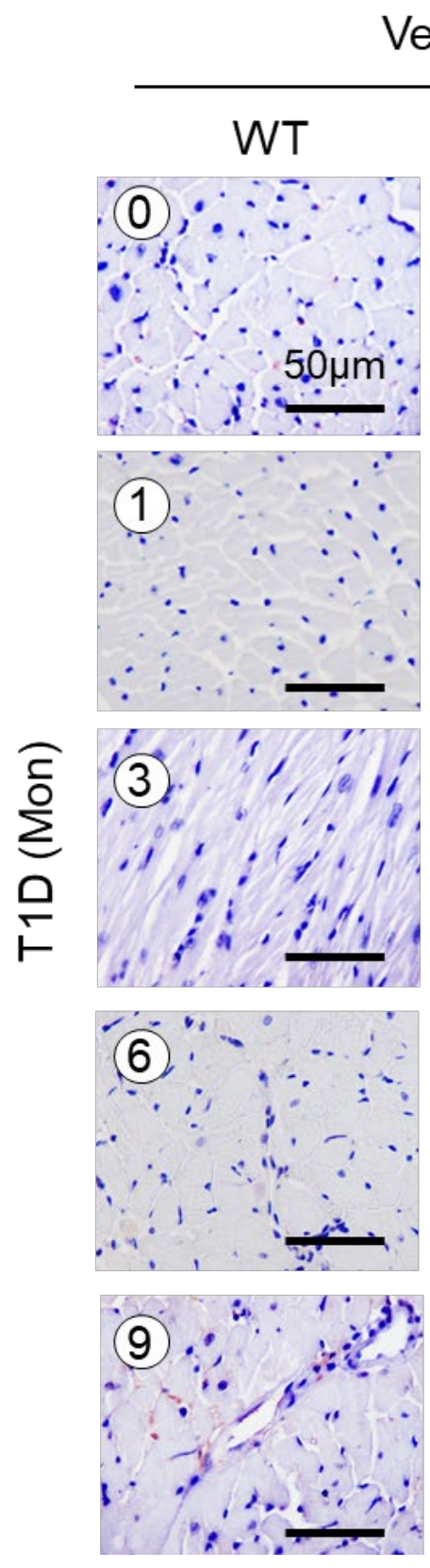

Veh
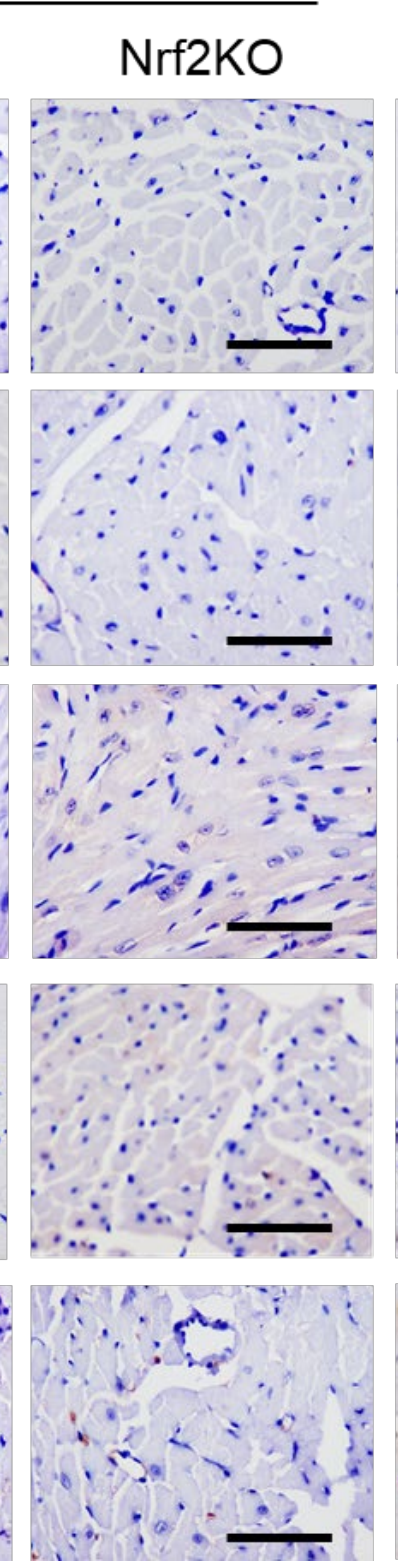

$q$

STZ
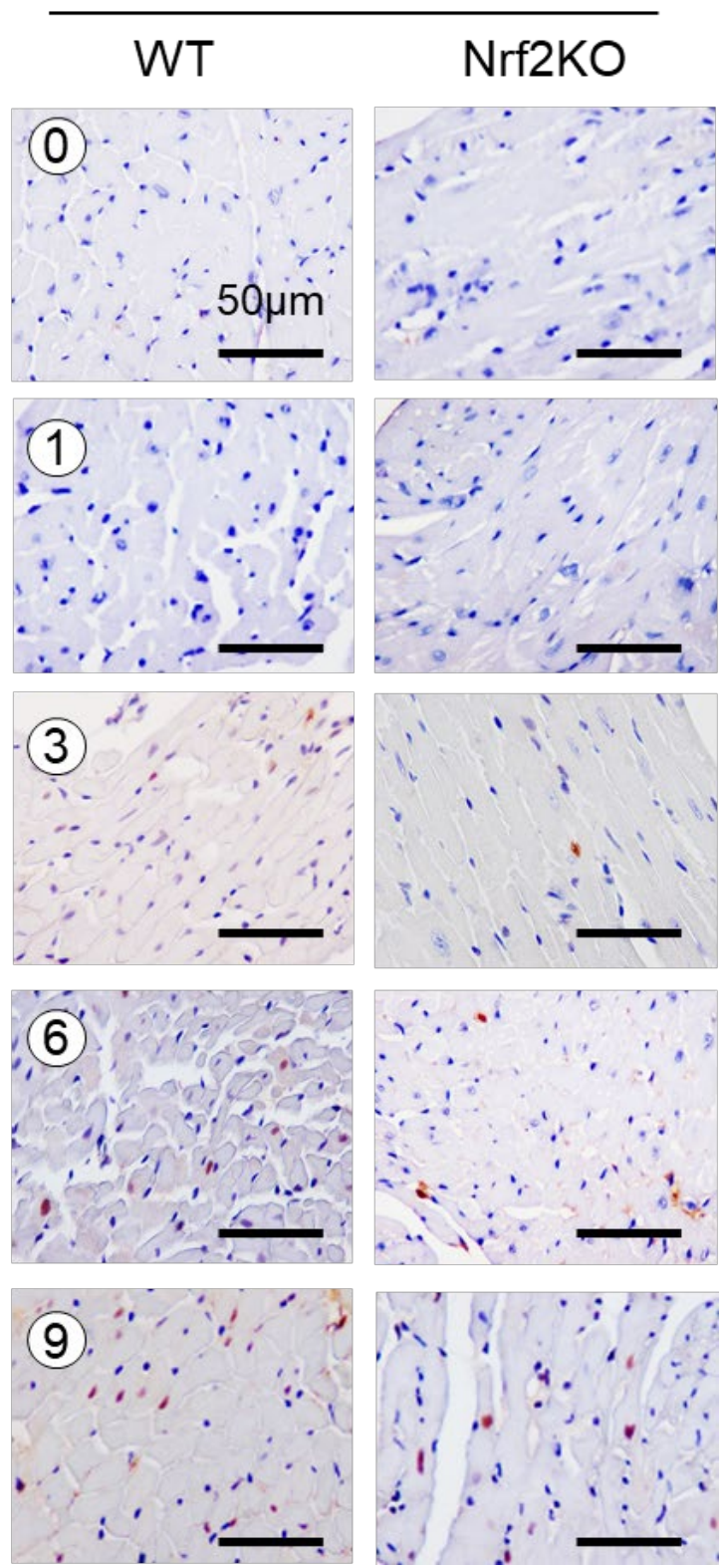

Supplementary Fig. 15. The impact of global knockout of Nrf2 on cardiac oxidative stressinduced DNA damage in STZ-induced type 1 diabetic female mice. The results are representative $8 \mathrm{OHdG}$ staining of Supplementary Fig. $10 \mathrm{~F}$ showing oxidative stress-induced DNA damage in the left ventricles (LVs) of female (q) WT and Nrf2KO mice at 0, 1, 3, 6, 9 months (Mon) after onset of STZ-induced type 1 diabetes (T1D). Scale bar $=50 \mu \mathrm{m}$. 


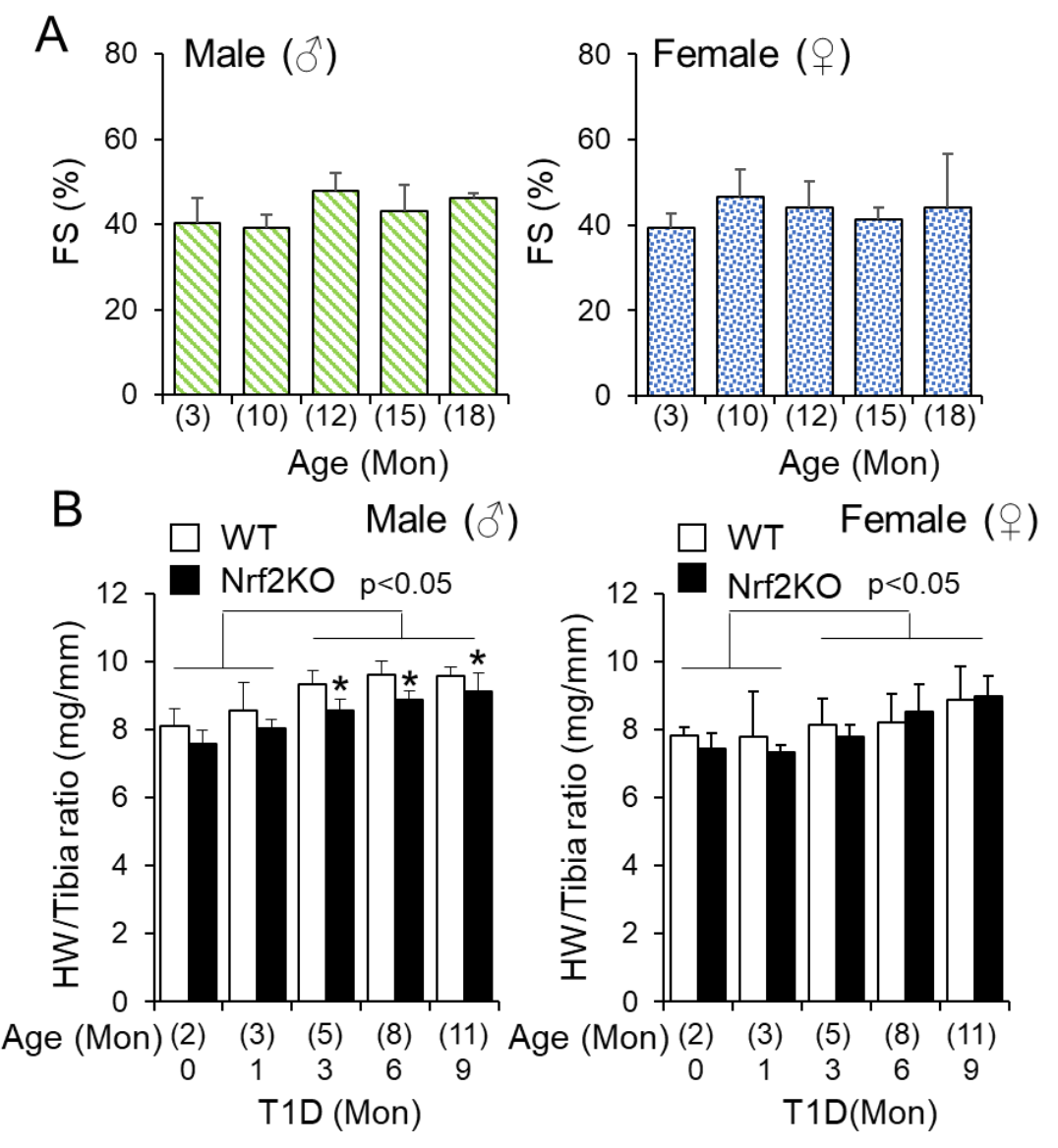

Supplementary Fig. 16. Baseline characterization of cardiac growth and function in WT and Nrf2KO mice during aging. $A$ : The impact of aging on cardiac function. FS (\%) of male $(\overbrace{}^{\lambda})(\mathrm{n}=8)$ and female $(+)(\mathrm{n}=6)$ wild type (WT) FVB/6N mice was monitored up to age of 18 months. $B$ : The heart weight $(\mathrm{HW}) /$ Tibia length ratio of male and female WT and Nrf2KO mice in a C57BL/6J genetic background was measured from ages of 2 months (Mon) to 11 Mon. $\mathrm{n}=4 \sim 12$ in each group, ${ }^{*}, p<0.05$ vs. WT groups at each time point. 

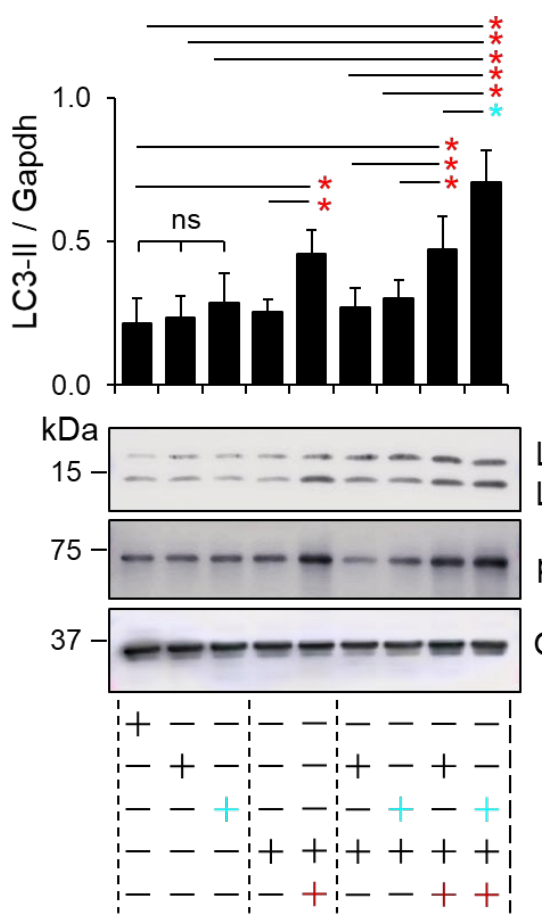

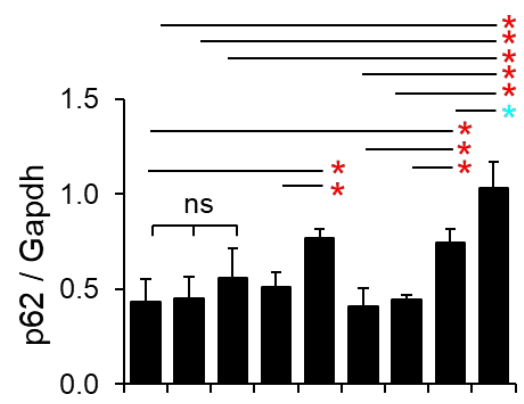

LC3-I NG; Normal Glucose

LC3-II M-Ctl; Mannitol

HG; High Glucose

BSA-Ctl; BSA alone

PA; BSA-palmitic acid overloading

Gapdh

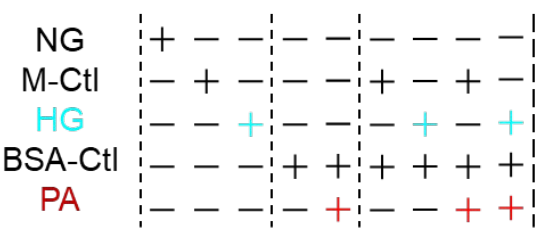

Supplementary Fig. 17. The effects of diabetic settings on LC3 and p62 expression in H9C2 cardiomyocyte-like cells. H9C2 cells were cultured until a confluent state in normal glucose (1 $\mathrm{g} / \mathrm{L}$ or $5.5 \mathrm{mmol} / \mathrm{L}$ ) DMEM supplemented 10\% FBS and $100 \mathrm{U} / \mathrm{ml}$ penicillin and $100 \mathrm{U} / \mathrm{ml}$ streptomycin in a $5 \% \mathrm{CO}_{2}$ incubator and then cultured with serum-free normal glucose DMEM (NG), mannitol (30 mmol/L) in normal glucose DMEM (M-Ctl), high glucose $(35.5 \mathrm{mmol} / \mathrm{L})$ DMEM, bovine serum albumin (BSA) control, and BSA-palmitic acids $(500 \mu \mathrm{mol} / \mathrm{L})$ as indicated for 24 hours $(n=4)$. The protein expression of LC3 and p62 was assessed by Western blot analysis. ${ }^{*}, p<0.05$ between indicated groups. ns, non-significant. 

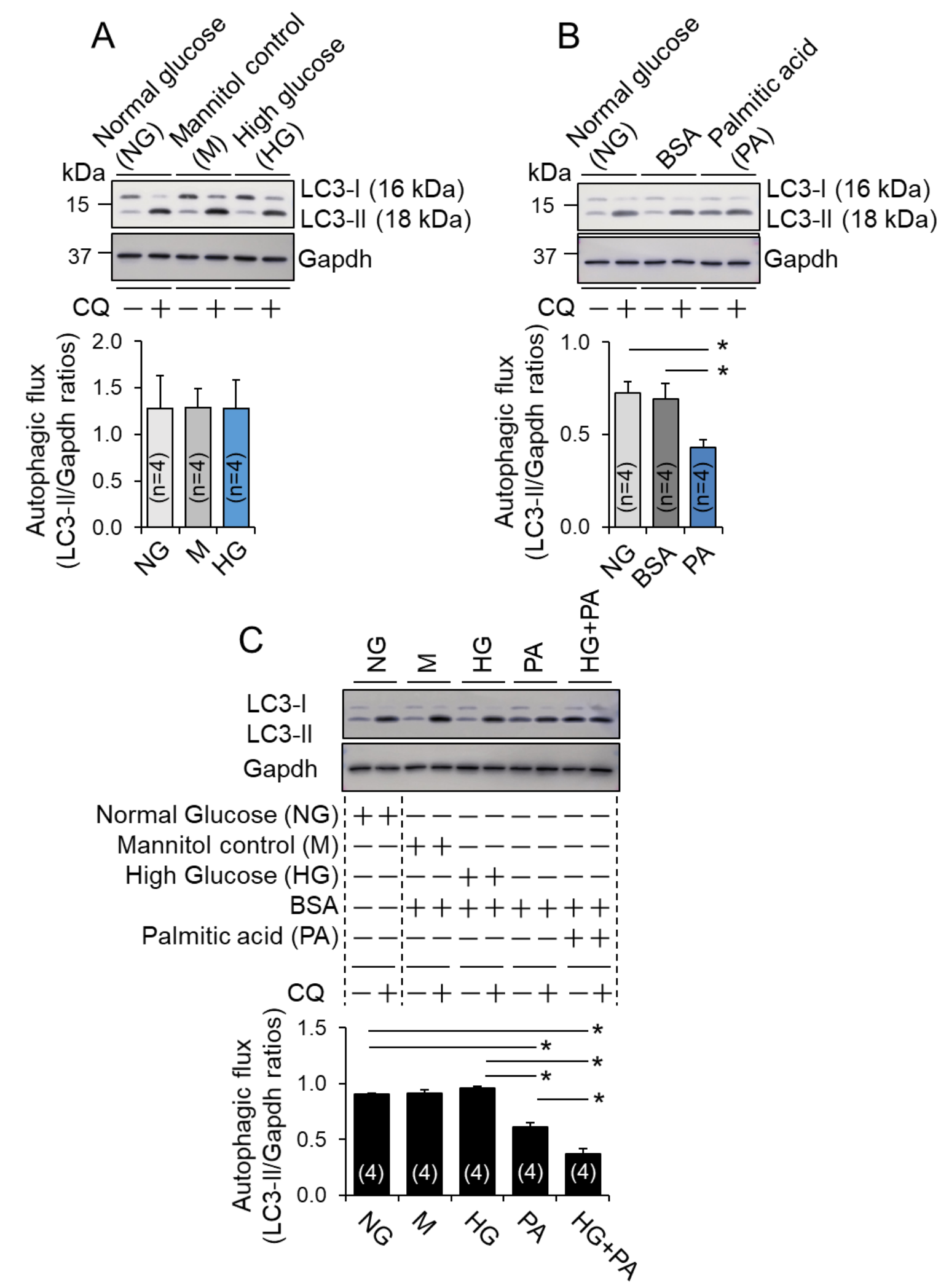

Supplementary Fig. 18. The effects of diabetic settings on autophagy flux in cardiomyocytelike H9C2 cells. H9C2 were cultured as described in Supplementary Fig. 17 with addition of 
chloroquine (CQ, $200 \mu \mathrm{mol} / \mathrm{L}$ ) during the last 2 hours of culture $(\mathrm{n}=4)$. A: CQ-induced LC3-II accumulation (autophagy flux) in $\mathrm{H} 9 \mathrm{C} 2$ cells at a setting of high glucose (HG) milieu. B: CQinduced autophagy flux in $\mathrm{H} 9 \mathrm{C} 2$ cells in a setting of lipid overloading. C: CQ-induced autophagy flux in $\mathrm{H} 9 \mathrm{C} 2$ cells in a setting of $\mathrm{HG}+$ lipid overloading. ${ }^{*}, p<0.05$ between indicated groups.
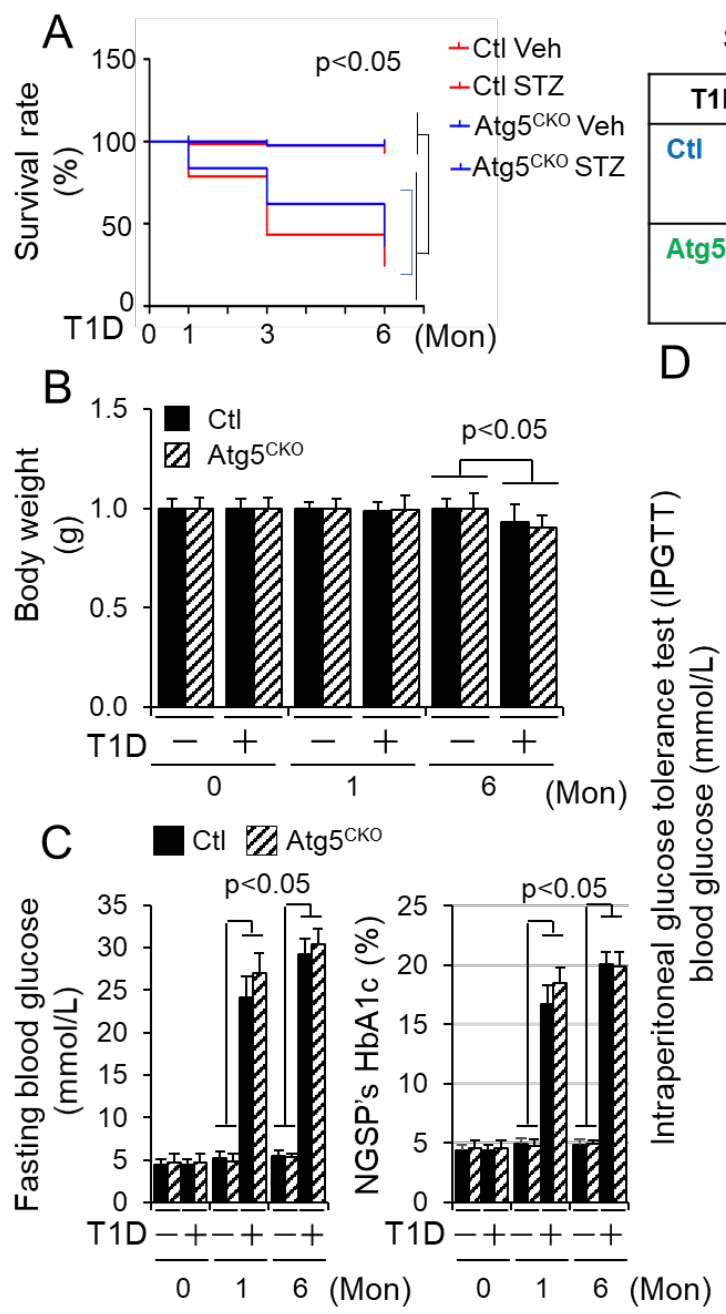

Survived animal numbers

\begin{tabular}{|c|c|c|c|c|c|}
\hline \multicolumn{2}{|c|}{ T1D (Months) } & 0 & 1 & 3 & 6 \\
\hline \multirow[t]{2}{*}{ Ctl } & Veh & 51 & 49 & 48 & 46 \\
\hline & STZ & 75 & 53 & 30 & 21 \\
\hline \multirow[t]{2}{*}{ Atg5 $5^{\text {СКо }}$} & Veh & 47 & 47 & 45 & 45 \\
\hline & STZ & 88 & 65 & 45 & 32 \\
\hline
\end{tabular}
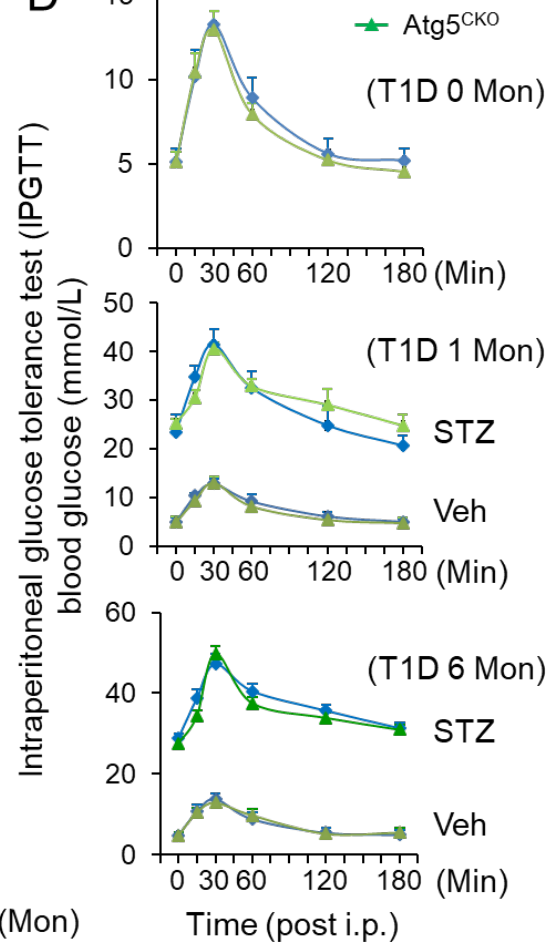

Supplementary Fig. 19. The impact of CR-Atg5KO on STZ-induced diabetes in female mice. Type 1 diabetes (T1D) in littermates of adult female ( $(+) \mathrm{MerCreMer}^{+}$control (Ctl) and MerCreMer ${ }^{+}: A \operatorname{Atg} 5^{\mathrm{fl} / \mathrm{fl}}$ (CR-Atg5KO) mice in a C57BL/6J genetic background after tamoxifen induction was induced by i.p. injection of STZ for 6 months (Mon) as described in Fig. 4A-B. A: Kaplan Meier analysis of survival rates. $B$ : Body weight changes at $0,1,6$ months after onset of diabetes. $C$ : Fasting blood glucose levels and NGSP's HbAlc (\%) at 0, 1, 6 months after onset of diabetes. $A-C$ : Animal numbers of each group are indicated in the inserted table. $D$ :

Intraperitoneal injection of glucose tolerance test (IPGTT) was performed at baseline $0,1,6$ months after onset of diabetes. Three to five animals of each group were randomly selected for the IPGTT. 

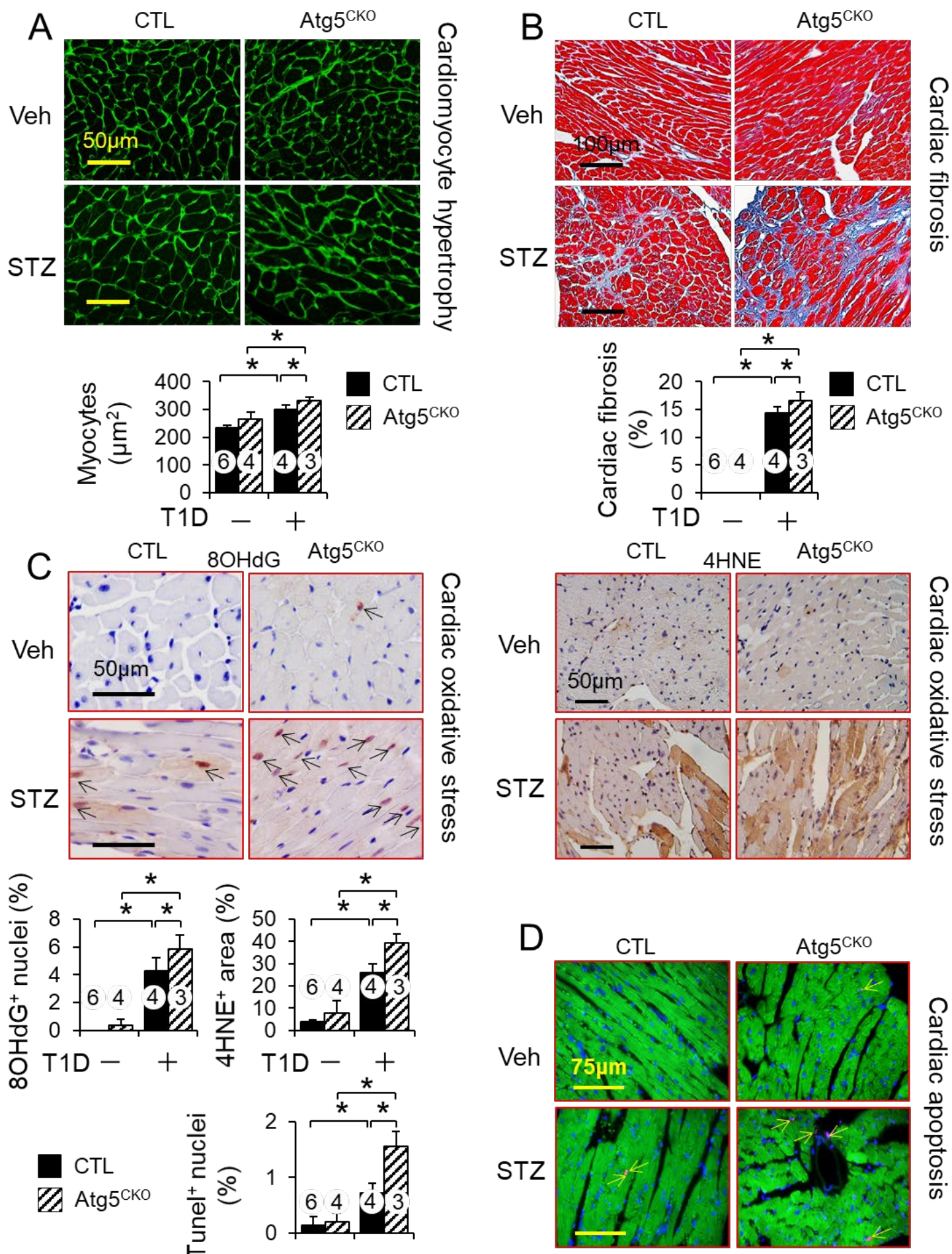

Supplementary Fig. 20. The impact of CR-Atg5KO on cardiac remodeling, cell death and oxidative stress associated with STZ-induced diabetes in female mice. Type 1 diabetes (T1D) in littermates of adult female (P) MerCreMer ${ }^{+}$control (Ctl) and $\mathrm{MerCreMer}^{+}:: \operatorname{Atg} 5^{\mathrm{fl} / \mathrm{ll}}$ (CRAtg5KO) mice was induced by injection of STZ for 6 months as described in Fig. 4A-B. 
Cardiomyocyte hypertrophy $(A)$, cardiac fibrosis $(B)$, cardiac oxidative stress $(C)$ and cardiac apoptosis $(D)$ in left ventricles (LVs) of MerCreMer+ control (CTL) and MerCreMer+::Atg $5^{\mathrm{fl} / \mathrm{fl}}$ $\left(\mathrm{Atg} 5^{\mathrm{CKO}}\right)$ after tamoxifen induction with indicated treatments were analyzed. The results included the representative staining of Fig. $4 B$.
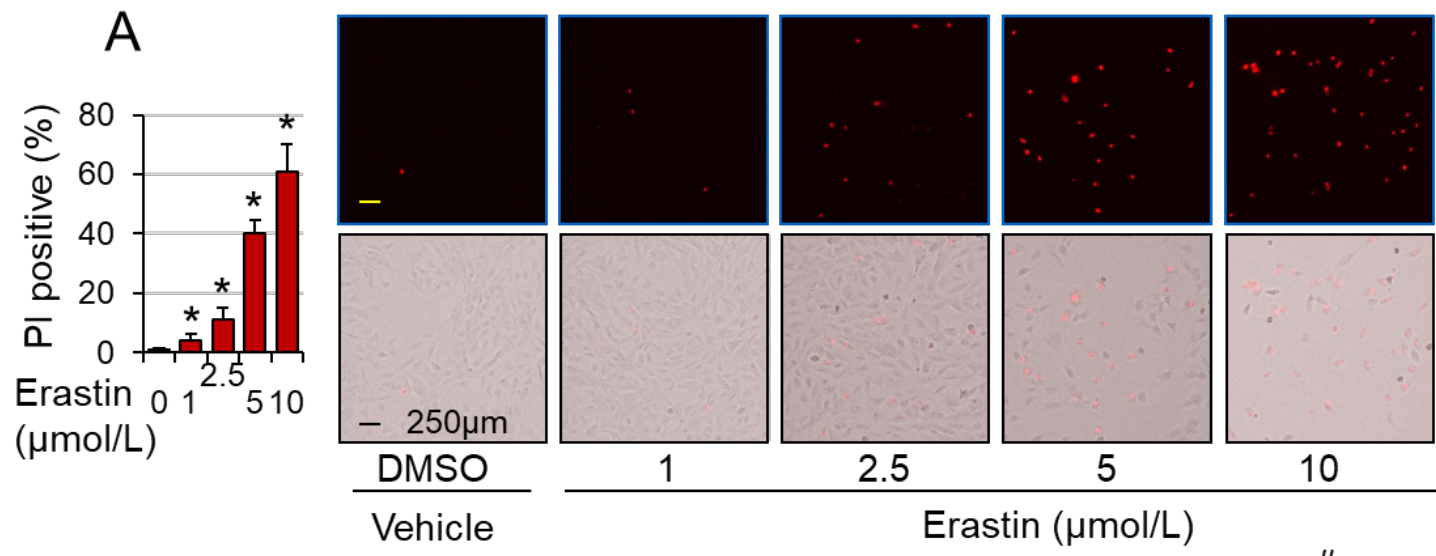

2.5 5 10
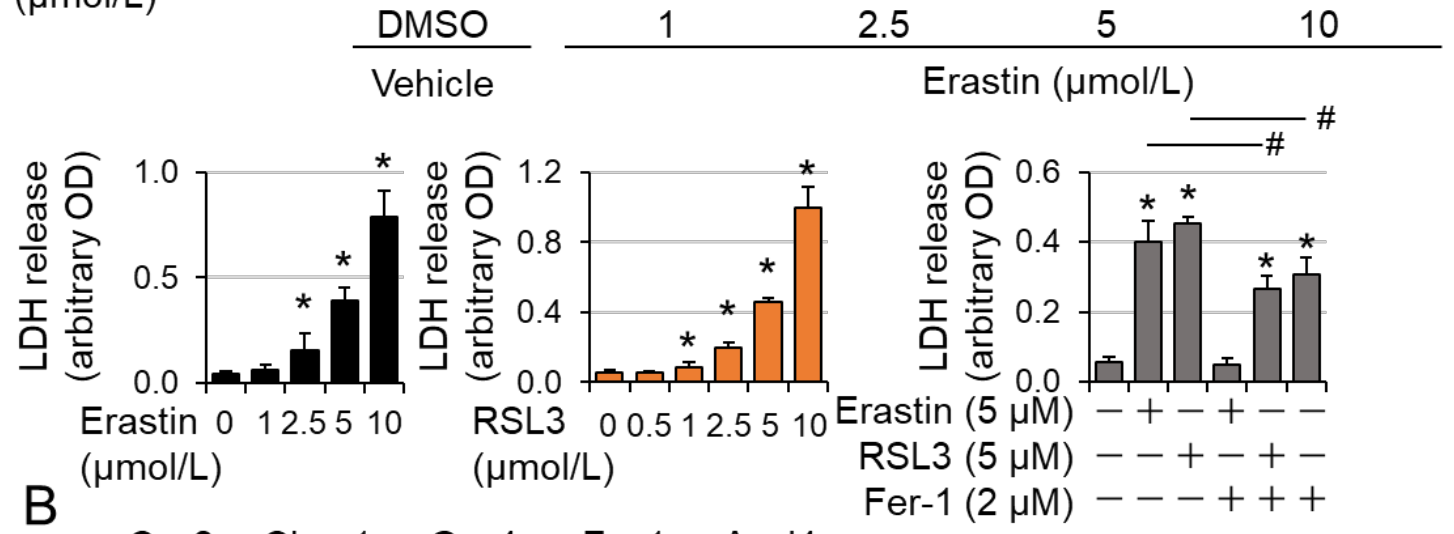

\section{B}

Cox2 Chac1 Gpx4 Fsp1 Acsl4

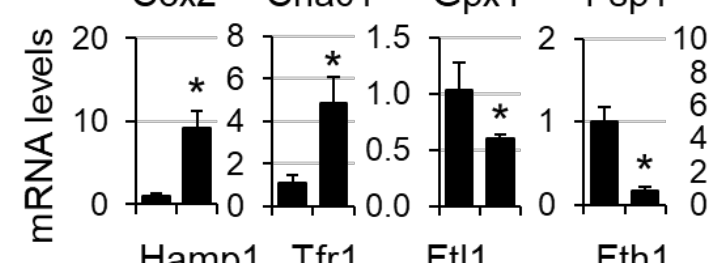
Hamp1 Tfr1 Ftl1 Fth1
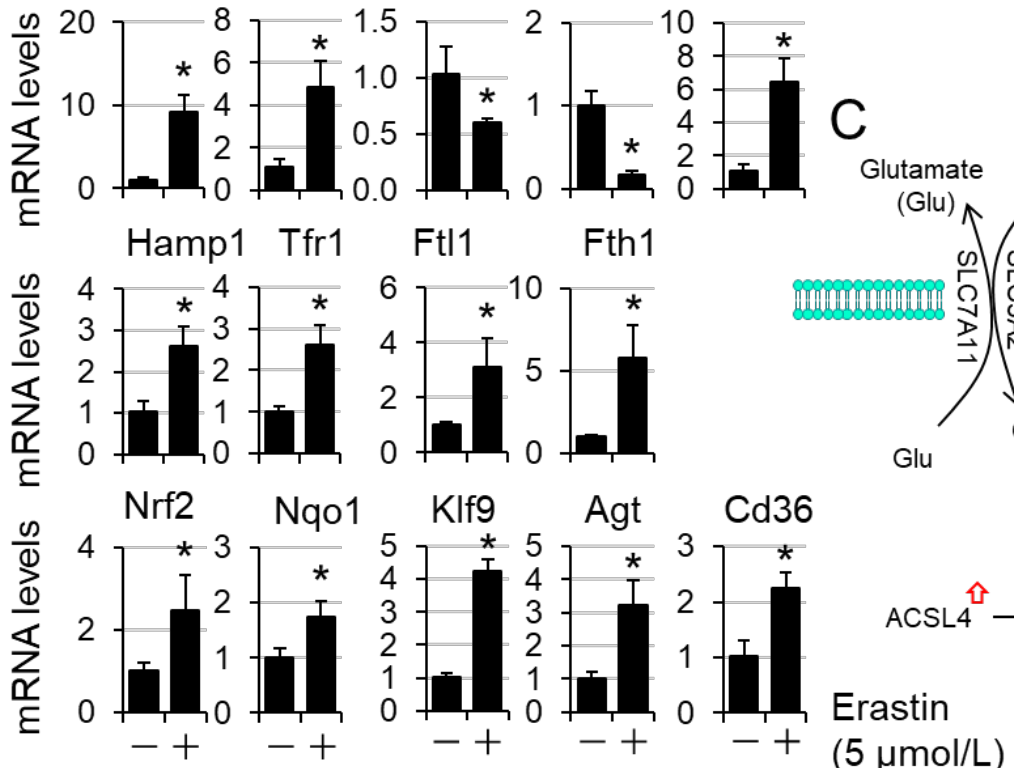

Cystine (Cys)
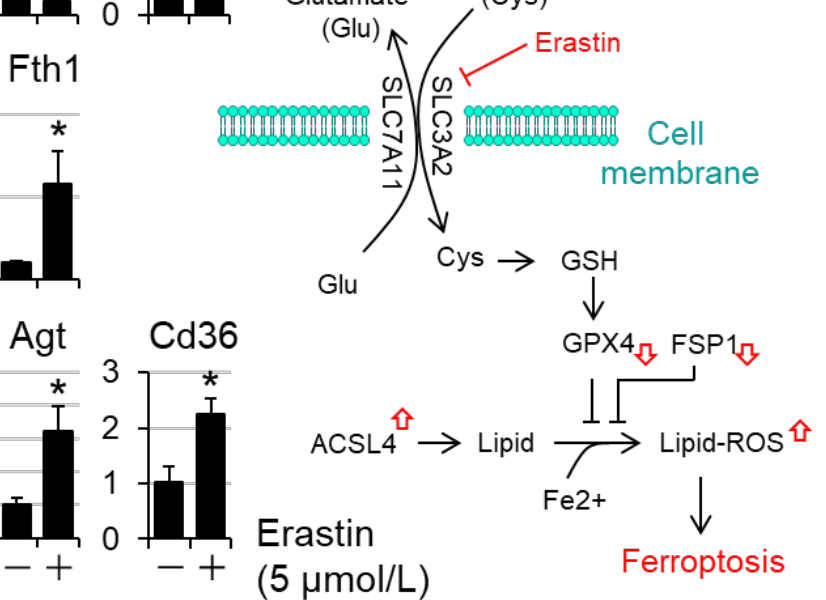

Supplementary Fig. 21. A potential role of Nrf2 in mediating ferroptosis in H9C2 cardiomyocyte-like cells. Sub-confluent H9C2 cells were treated with erastin, RSL3, and ferrostatin-1 (Fer-1) in serum-free DMEM for 24 hours and then were subject to assessments of 
cell death or gene expression as indicated. A: Cell death. Upper left: Quantified PI positive cells (\%). Upper right: The representative propidium iodide (PI) staining. Lower panel shows erastinor RSL3-induced ferroptosis. $\mathrm{n}=4,{ }^{*}, p<0.05$ between indicated groups. $B$ : qPCR analysis of gene expression. $\mathrm{n}=4,{ }^{*}, p<0.05$ between indicated groups. $C$ : A scheme of erastin-induced signaling network for driving ferroptosis in $\mathrm{H} 9 \mathrm{C} 2$ cardiomyocyte-like cells. Erastin inactivates GPX4, downregulates FSP1, and upregulates ACSL4, thereby promoting lipid peroxidation towards ferroptosis. 

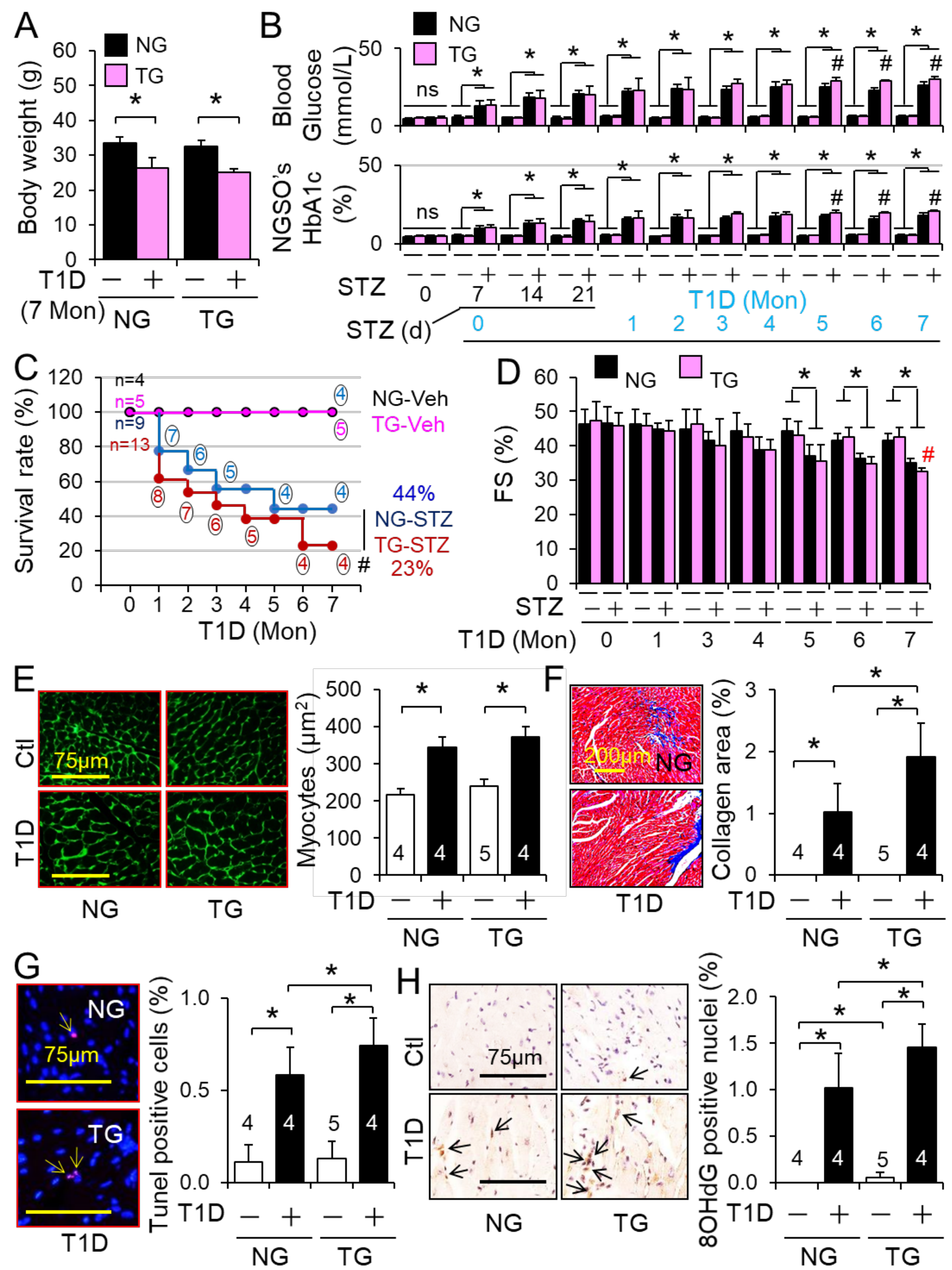

Supplementary Fig. 22. The effect of CR-Nrf2 overexpression on type 1 diabetes-induced cardiomyopathy in female mice. Type 1 diabetes (T1D) in littermates of adult female ( $($ ) non- 
transgenic wild type (NG) and CR-Nrf2 transgenic (TG) mice in a FVB/N genetic background was induced by i.p. injection of STZ for 7 months (Mon) and STZ-induced T1D and pathologies were assessed as described in "Research Design and Methods". A: Body weights of NG and TG mice at 7 months after onset of diabetes. ${ }^{*}, p<0.05$ between indicated groups. $B$ : Fasting blood glucose levels and NGSP's HbA1C (\%) of NG and TG mice over a time period of 7-month onset of diabetes. ${ }^{*}, p<0.05$ between indicated groups; \#, $p<0.05$ vs STZ treated NG at the same time point. $C$ : Survival rates. \#, $p<0.05$ vs NG treated with vehicle (Veh). $D$ : Cardiac function, FS (\%). ${ }^{*}, p<0.05$ between indicated groups; \#, $p<0.05$ vs STZ treated TG at 7 months. Animal numbers of each experimental groups $(A-D)$ are indicated in $C$. $E$ : Cardiac myocyte size. $F$ : Cardiac fibrosis. $G$ : Cardiac apoptosis. $H$ : Cardiac oxidative stress. $E-H$ in left ventricle (LV) tissue sections of NG and TG mice at 7 months after onset of diabetes were analyzed. Animal numbers of each experimental groups $(E-H)$ are indicated in each figure. ${ }^{*}, p<0.05$ between groups. d; day. 


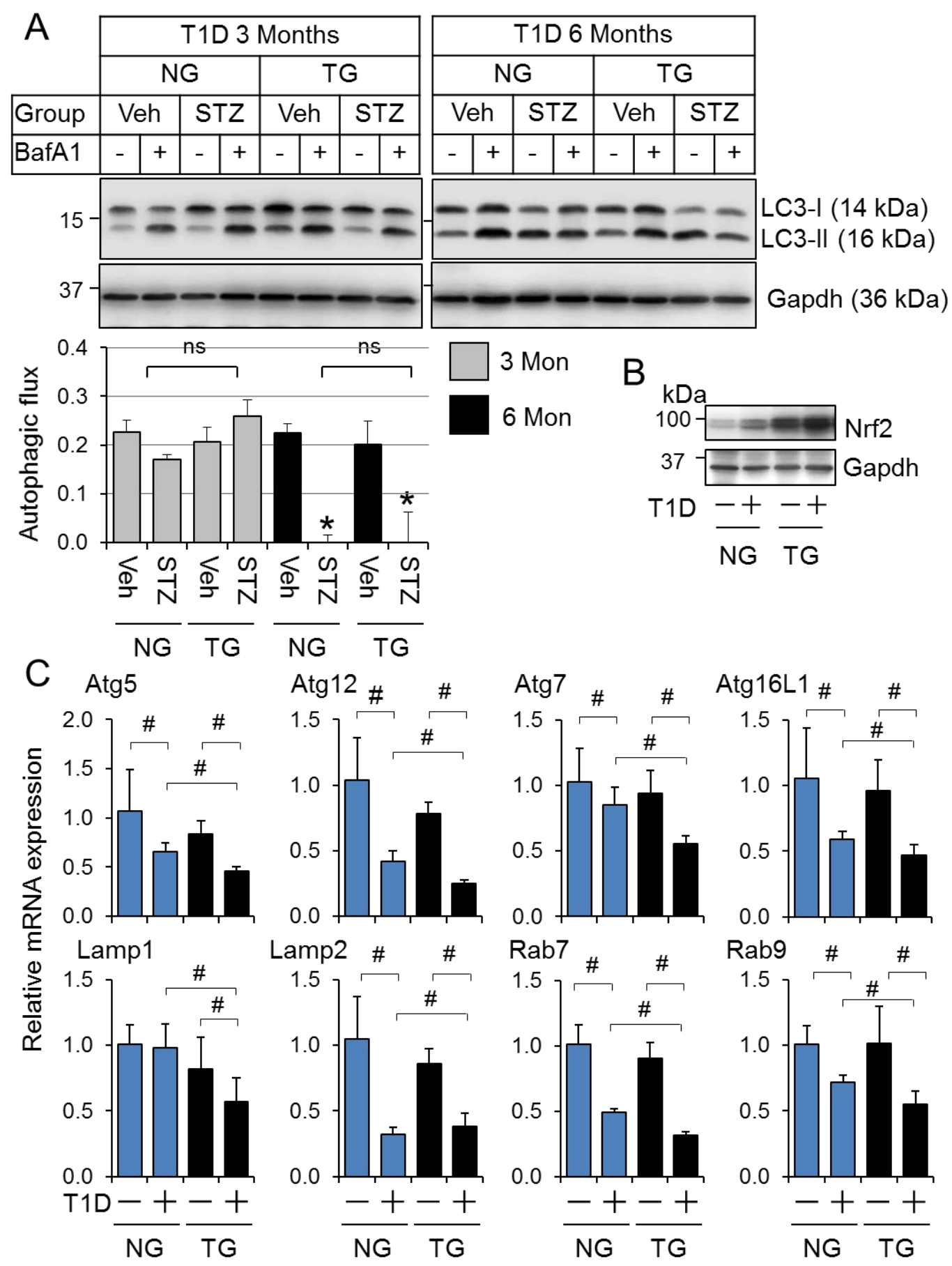

Supplementary Fig. 23. The impact of CR-Nrf2 overexpression on cardiac autophagy in STZ-induced diabetic male mice. Type 1 diabetes (T1D) in littermates of adult male ( $\delta$ ) nontransgenic WT (NG) and CR-Nrf2 Tg (TG) mice in a FVB/N genetic background was induced by i.p. injection of STZ for 6 months (Mon) and then were subject to the assessments of myocardial autophagic flux, and genes or protein expression in left ventricles (LVs) as indicated. $A$ : The impact of CR-Nrf2 overexpression on T1D-induced suppression of cardiac autophagic flux in mice. The upper panel is the representative immunoblots and the lower panel is the 
autophagic flux (n=4). ns, non-significant; ${ }^{*}, p<0.05$ vs. Veh controls in the same groups. $B$ : Representative immunoblots of Nrf2 protein expression in NG and TG mice. $C$ : Relative mRNA expression of autophagy related genes in the heart at 6 months after onset of diabetes. $\mathrm{n}=4$; $\#, p<$ 0.05 between indicated groups.

A Ferroptosis markers

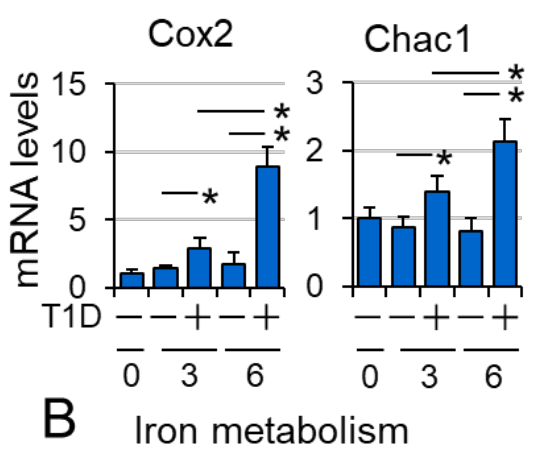

Tfr1

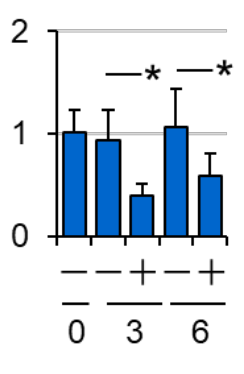

Ferroptosis regulators

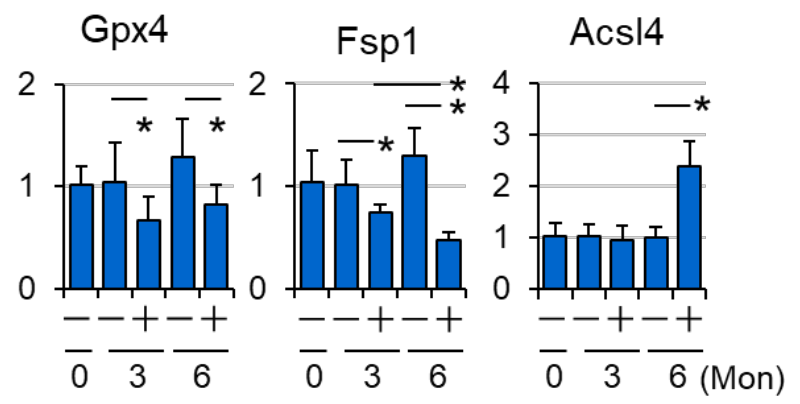

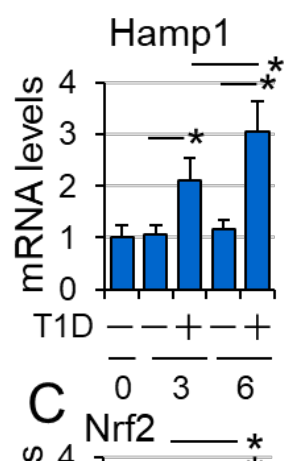

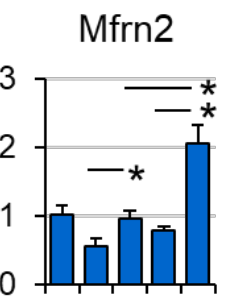

Fth1
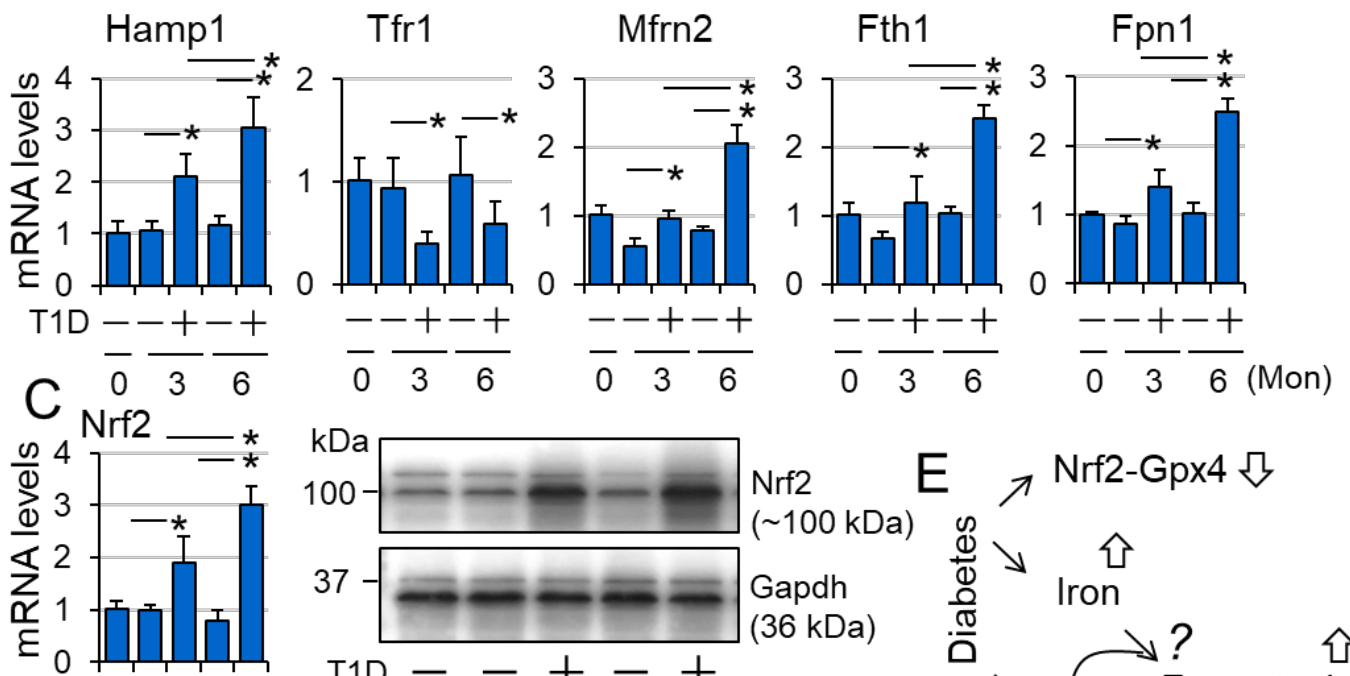

T1D
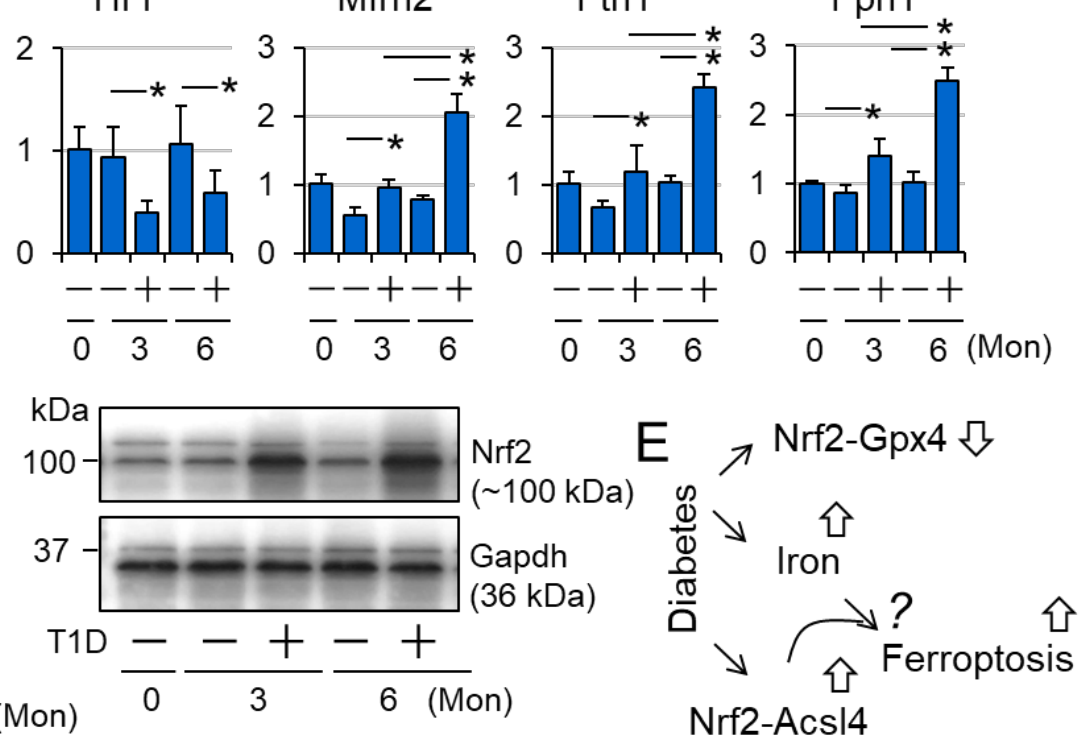

Nrf2-Acsl4

D Nrf2 target genes

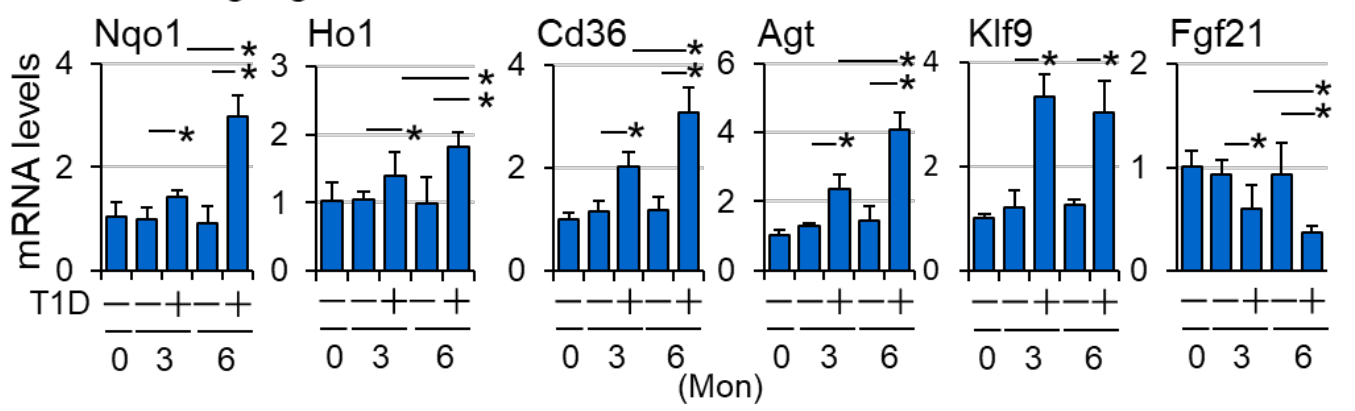

Supplementary Fig. 24. The impact of type 1 diabetes on myocardial Nrf2 signaling in male mice: Potential activation of Nr2-mediated ferroptosis? Type 1 diabetes (T1D) in adult male $\left({ }^{3}\right)$ wild type mice in a FVB/N genetic background was induced by i.p. injection of STZ for 6 months (Mon) and then were subject to the assessments of myocardial gene or protein expression 
as described in "Research Design and Methods". Left ventricle tissues of the NG and TG mice were used to measure gene and protein expression as follows: $A$ : Relative mRNA expression of ferroptosis marker and regulator genes. $B$ : Relative mRNA expression of genes regulating iron metabolism. $C$ : Nrf2 expression. Left panel shows relative Nrf2 mRNA expression and right panel show Nrf2 protein expression. Representative immunoblotting of Nrf2 protein expression from 4 separated experiments. Western blot analysis was carried out using whole heart tissue lysates. $D$ : Relative mRNA expression of typical Nrf2 downstream genes. All results are representatives of several sets of separated experiments $(\mathrm{n}=4$, duplicated qPCR and Western blot analyses). ${ }^{*}, p<0.05$ between indicated groups. $E$ : A working hypothesis. Diabetes over time impairs Nrf2-operating antioxidant defense, such as GPX4 expression and activity, while intensifying Nrf2-driven pathological gene program including ACSL4 expression, thereby activating ferroptosis in the heart.

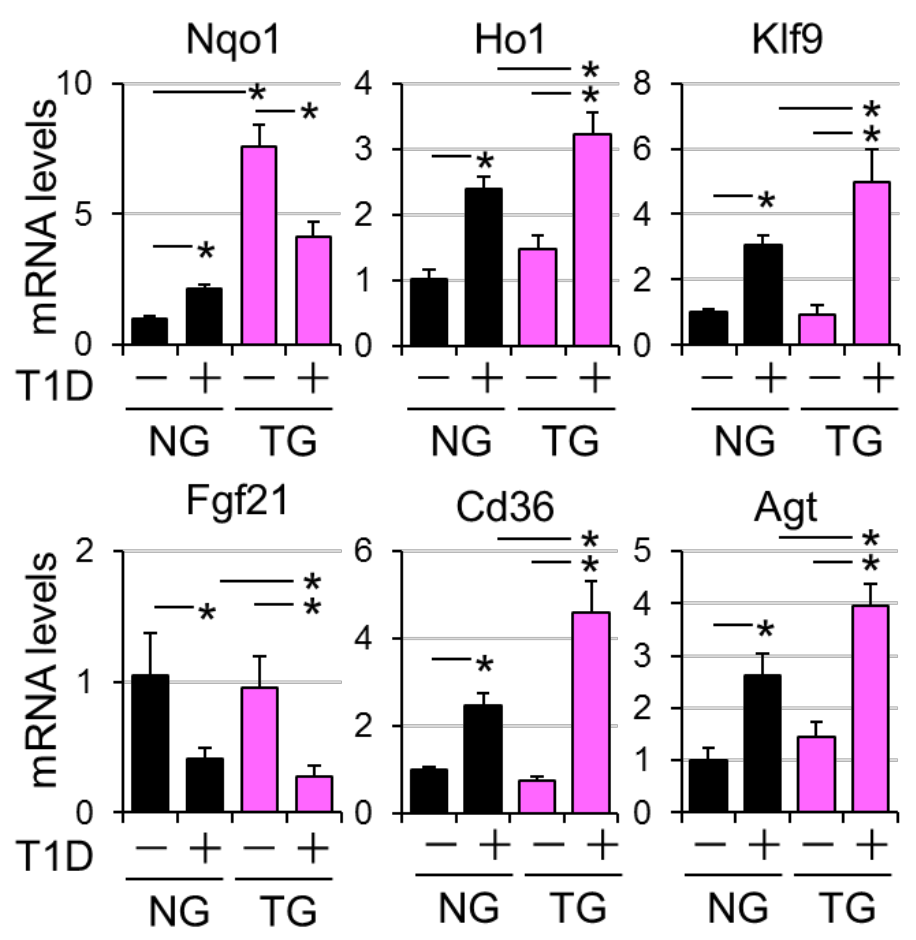

\footnotetext{
Supplementary Fig. 25. The effect of CR-Nrf2 overexpression on type 1 diabetes-induced dysregulation of myocardial Nrf2 signaling in male mice. Type 1 diabetes (T1D) in littermates of adult male $\left({ }^{\lambda}\right)$ non-transgenic wild type (NG) and CR-Nrf2 transgenic (TG) mice in a FVB/N genetic background was induced by i.p. injection of STZ for 6 months (Mon) and then were subject to qPCR analysis of myocardial gene expression as described in "Research Design and Methods". Left ventricles of the NG and TG mice were used to measure gene expression $(\mathrm{n}=4) .{ }^{*}, p<0.05$ between indicated groups.
} 